\title{
Nagylepke fauna felmérés a Baláta-tó Természetvédelmi Területen (Lepidoptera: Macrolepidoptera)
}

\author{
ÁBRAHÁM LEVENTE \\ Rippl-Rónai Múzeum, Kaposvár, Fő utca 10., \\ e-mail: labraham@smmi.hu
}

\begin{abstract}
ÁBRAHÁM, L: Large butterfly and moth fauna survey of the Lake Baláta Nature Reserve (Lepidoptera: Macrolepidoptera). Abstract: Between 1986-1997, large butterfly and moth fauna was examined in the Lake Baláta Nature Reserve (Somogy county). In 1987, a light trap was operated for a year in Kanizsaberek, the closest settlement to the protected area, and the further faunistic investigation was carried out by lighting in the other three points of the protected area. The butterflies were collected along forest roads, the narrow-gauge railway and deforestation area. During the investigation, 68 butterfly and 401 moth species were found. 8190 specimens were collected by the light trap, which belonging to 367 species. According to cited literature and the present study, the number of species known from the area is 504 (73 butterflies, 431 moths). The fauna is characterized by the high number of birch and alder consumer species, which can be related to the the moorland. The number of protected species is 43 and 5 species of Natura 2000 (Lycaena dispar, Maculinea nausithous, Maculinea teleius, Proserpinus proserpina, Euplagia quadripunctaria) were found.
\end{abstract}

Keywords: Macrolepidoptera, faunistics, nature conservation, Lake Baláta, Hungary.

\section{Bevezetés}

Somogy megye Európa szerte legismertebb lápterülete a Baláta-tó Természetvédelmi Terület. A tó kifejezés valójában nem pontos, mivel a terület tájtörténetét tekintve helyesebb lenne inkább Baláta-láp területről beszélni (Kasza és Marián 2001).

A Baláta-tó természeti értékeinek megismerése - sok más hasonló hazai területhez - az 1920-as években kezdődött el, mivel Magyarország határai ekkorra jelentősen megváltoztak. A hazai természettudományi kutatások súlypontja ebben az időben helyeződött át a Kárpátok magashegyvidékéröl, és a Tengermellék mediterrán területéről a Kárpát-medence belső részére.

A terület természeti értékekben való gazdagságára először Boross Ádám 1924-es expedíciója hívta fel a figyelmet, amikor a Baláta talán ma is a legközismertebb növényének első populációját, az Aldrovanda vesiculosa fajt felfedezte. Nem sokkal később (1927) több zoológus (Dudich E., Éhik Gy., Vásáthelyi I.) is felkereste a területet, akik a keresztes vipera fekete változatát (Vipera berus var. prester) találták itt meg először hazánkban. A természeti értékek gazdagságának köszönhetően a terület Somogy megyében elsőként kapott hivatalosan védettséget még 1942-ben.
A védett terület természeti értékeinek további feltárását az 1950-es években Marián (1956, 1957, 1958) zoológiai kutatásai, valamint Borhidi és Járai-Komlódi (1959) vegetációt feltáró vizsgálatai tették még ismertebbé Európa szerte.

A Baláta és környéke az 1980-as évek végéig honvédségi zárt terület volt, arra ugyanazon szabályok vonatkoztak, mint a határvidékre, azaz csak külön belépési engedéllyel lehetett kutatásokat végezni a területen. A viszonylagos elzártság csökkentette a kutatók érdeklődését a terület iránt. Így a Baláta és környéke átfogó természetvédelmi alapfauna feltárása még mind a napig nem valósult meg. Az elmúlt évtizedekben egyegy részterületen számos kiváló dolgozat és kutatási jelentés született (Ábrahám \& Papp 1991, Bérces 2002, Borhidi et al. 1990, Józan 1996, Haris 2012, Kasza és Marián 2001, Majer 1992, Majer et al. 2002, Tóth 2010). A közelmúltban látott napvilágot a terület környezettörténetét feltáró alapmű (Sümegi et al. 2014).

A Baláta környéki nagylepke faunáról viszonylag kevés ismeret állt rendelkezésünkre. A terület első kutatója Nattán Miklós volt, aki már az 1930 évek végétől kezdve többször végzett itt alkalmi lámpázást, és nappali gyűjtést. Gyűjteményi adatairól Kovács $(1953,1956)$ adott hírt, a nagylepke fauna hazai elterjedési adatainak első összefoglalásában. 81 fajt sorolt fel a Baláta környékéről Nattán Miklós gyüjtései alapján. Ebből 18 faj (Marumba quercus ([Denis \& Schiffermüller], 1775), Boudinotiana notha (Hübner, 1803), Eupithecia pyreneata Mabille, 1871, Hypomecis danieli (Wehrli, 1932), Cleorodes lichenaria (Hufnagel, 1767), Setina roscida ([Denis \& Schiffermüller], 1775), Euclidia mi (Clerck, 1759), Tyta Iuctuosa ([Denis \& Schiffermüller], 1775), Calamia tridens (Hufnagel, 1766), Pabulatrix pabulatricula (Brahm, 1791), Lithophane ornitopus (Hufnagel, 1766), Lithophane furcifera (Hufnagel, 1766), Xylena exsoleta (Linnaeus, 1758), Xylena vetusta (Hübner, 1813), Heliophobus reticulata (Goeze, 1781), Conisania luteago ([Denis \& Schiffermüller], 1775), Pyrgus carthami (Hübner, [1813]), Lycaena alciphron (Rottemburg, 1775)) a későbbi vizsgálatok során nem került elő.

Ezt követően Ábrahám (1989), a Nattán-féle nagylepkegyűjtemény feldolgozása során a Baláta környékéről is közölt további adatokat, amelyek közül csak a Carterocephalus palaemon (Pallas, 1771) és a Scolitantides orion (Pallas, 1771) előfordulását nem erősítették meg a későbbi vizsgálatok. 
Somogy megye nagylepke faunájának annotált adatait Ábrahám és Uherkovich (2001) tette közzé, ebben a Baláta környékéröl publikált adatok (Kovács 1953, Ábrahám 1989) is összegzésre kerültek.

A szerző az 1980-as évek végén nagylepke fauna feltáró munkába kezdett, de ez a kutatómunka az 1987es rendszeres nappali és éjszakai gyűjtések, valamint Kanizsaberekben felállított fénycsapda anyagának a feldolgozása után megszakadt, mert annak anyagi finanszírozása nem volt megoldott. Később a Dráva-mellék kutatása és a terület nemzeti parkká történő fejlesztése - amelyben a szerző is aktívan részt vett - lekötötte a kutatási kapacitásait. A faunafeltáró munka kutatási eredményeinek publikálása pedig elmaradt. Bár az adatok egy része Ábrahám (1995) által készített kutatási jelentés formájában hozzáférhető volt.

1997-ben a nemzeti park munkatársai három alkalommal helyeztek ki a területre hordozható fénycsapdát, ennek anyagát Uherkovich (1997) dolgozta fel. Ebben a kutatási jelentésben 8 olyan faj (Gastropacha quercifolia (Linnaeus, 1758), Cyclophora quercimontaria (Bastelberger, 1897), Anticollix sparsata (Treitschke, 1828), Pasiphila rectangulata (Linnaeus, 1758), Eupithecia pygmaeata (Hübner, 1799), Parectropis similaria (Hufnagel, 1767), Chariaspilates formosaria (Eversrnann, 1837), Amata phegea (Linnaeus, 1758)) is található, amely korábban nem volt ismert a területröl.

A Baláta környéki zoológiai felmérések hozzájárultak ahhoz, hogy a terület, Szentai-erdő (HUDD20063) néven kiemelt természetmegőrzési területté nyilvánítsák.

Jelen dolgozat célja, hogy növelje a természeti értékekről, különös tekintettel a nagylepkékre vonatkozó ismereteinket a Baláta környékéről.

A ma már Natura 2000 területen a kutatások új szakasza is elkezdődött, 2008-ban a Baláta-tó Természetvédelmi Terület bekerült a hazai erdőrezervátumok sorába, és megkezdődött a Natura 2000 nagylepke fajok populációjának felmérése is. A jövőben megjelenő tudományos publikációk immár majd ezekről fognak beszámolni.

\section{Anyag és módszer}

A nappali lepkék egyelő, hálós gyűjtésén - és sok esetben puszta megfigyelésén - kívül a legfontosabb felmérési módszer a személyes éjjeli gyűjtés és a fénycsapda volt.

Személyes éjjeli gyűjtések során egy 160 wattos kevert fényű lámpát (HMLI) alkalmaztam, amelyet egy kb. $8 \mathrm{~m}^{2}$ felületű, áttetsző anyagú fehér lepedő előtt állítottam fel. Emellett a gyűjtőlepedő egyik oszlopánál egy 20 wattos „fekete fényü” UV fénycsővel is világítottam, hogy a szövő- és a bagolylepkéket még hatékonyabban csalogassam a gyújtőlepedőhöz.

A mintavételezések az 1986-os év végétől és az 1995-ös év elejéig történtek.

A faunafeltárás hatékony eszközeként Kanizsaberekben 1987-ben egy fénycsapdát állítottam fel. Ez egy ún. Jermy-típusú fénycsapda volt, amelynek tölcsére felett még egy terelölemezt helyeztem el. A fénycsap- dában 125 wattos higanygőz lámpa (HGLI) üzemelt. Sajnos a fénycsapda müködtetése nem volt teljesen folyamatos, július közepétől augusztus közepéig vagy szünetelt, vagy a gyűjtött anyag részben penészessé, és ennek következtében határozhatatlanná vált.

A mintavételi területeket az előzetes terepbejárások alapján választottam ki úgy, hogy abban a védett területre jellemző élőhelytípusok szerepeljenek.

A nappali gyűjtések súlypontja Kanizsaberek száraz és mezofil gyepjeiben, a kiszáradó láprét jellegű, kaszálóként művelt Tuskósi-réten, valamint az erdei utak és lineák mentén történt.

A Baláta körül három különböző mintavételi helyen végeztünk személyes éjszakai gyűjtést (1. ábra).

$A z$ 1. mintavételi helyen üde gyertyános-tölgyesek (Querceto robori-cerris carpinetosum) és cseres-tölgyesek (Quercetum robori-cerris pteridietosum) váltakoznak a hullámos homokhátaknak megfelelően.

A 2. mintavételi hely jellemző növénytársulását égeresek (Cariceto elongatae-Alnetum) képviselték.

A 3. mintavételi területén, a Bojsza-tó mellett a vegetáció nagyon változatos volt. $\mathrm{A}$ fenti társulások mellett füzlápok (Calamagrostis Salicetum cinerae), nádasok (Scirpo-Phragmitetum) és gyékényesek (Scirpo-Phragmitetum typhetosum) is megjelentek. Ezen kívül a területen égeresek, ültetett erdei fenyves (Pinus sylvestris) és a már mezofil jellegű termőhelyeken pl. a kisvasút töltésén degradált társulások (Solidago sp.) is elfordultak.

Kanizsaberekben a fénycsapda felállítási helyén változatos volt a vegetáció, a természetes növénytársulások közül az üde gyertyános-tölgyesek (Querceto robori-cerris carpinetosum) és cseres-tölgyesek (Quercetum robori-cerris pteridietosum) domináltak, kisebb kiterjedésben égerliget is előfordult. A település környékén helyenként félszáraz, elgyomosodott homoki gyepek, valamint a mezőgazdasági jellegéből adódóan, másodlagos növénytársulások (gyümölcsösök) is jellemzőek voltak.

A mintavételi anyag meghatározása kb. 20 éve befejeződött, de a faunalista közzétételére a napjainkban használatos nevezéktan (Varga 2012) alapján kerül sor. A begyűjtött anyagot a Rippl-Rónai Múzeum entomológiai gyűjteménye őrzi.

\section{Eredmények és megvitatás}

A Baláta-tó Természetvédelmi Területen 1986 végétől 1995 közepéig alkalmi éjszakai lámpázásokat végeztem, és a hozzá legközelebb eső Kanizsaberek településen 1987-ben, egy vegetációs időszakban fénycsapdát müködtettem.

A nappali lepkéket - a jórészt zárt erdőkkel borított helyeken - a lineák, az erdei utak és a kisvasút mentén gyűjtöttem. A védett terület szomszédságában két eltérő jellegű nyíltabb mintavételi hely volt. Kanizsaberek település környékén mezofil és száraz zárt homoki gyepekben, a Tuskósi-réten kiszáradó, kezelt lápréteken történt a mintavételezés. 


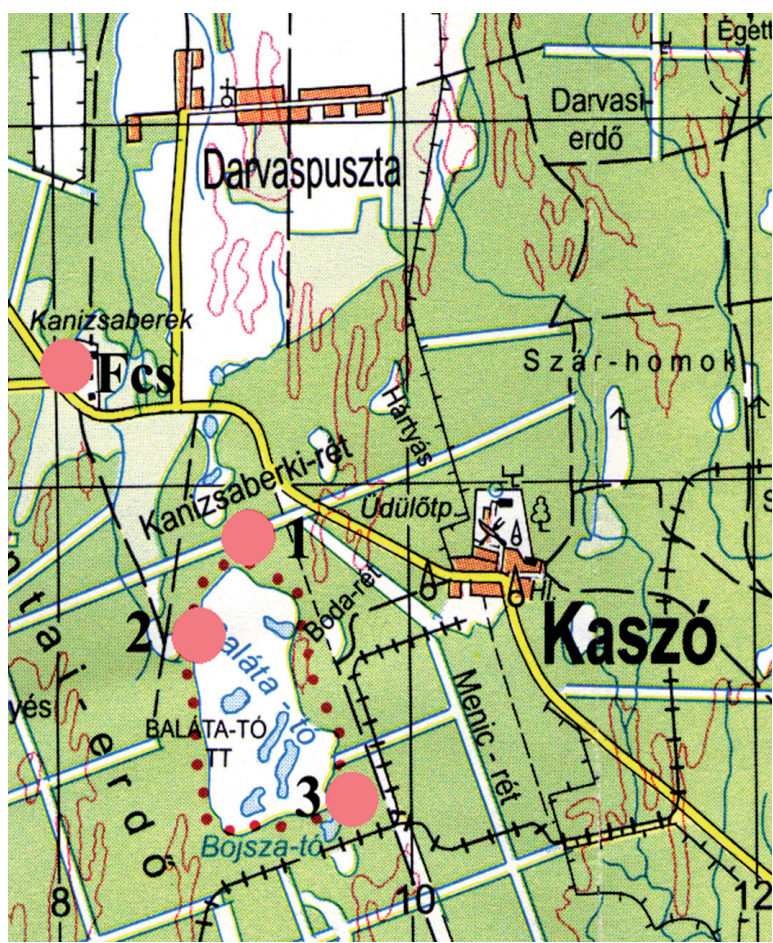

1. ábra. Mintavételi terület elhelyezkedése a Baláta-tó mellett

Fcs - fénycsapda, 1-3. lámpázási helyek

A nappali lepkefauna nem bizonyult túl gazdagnak, összesen: 68 faj került elö. Kovács (1953) és Ábrahám (1989) Nattán Miklós által gyűjtött további öt nappali lepke fajt (Pyrgus carthami (Hübner, [1813]), Carterocephalus palaemon (Pallas, 1771), Lycaena alciphron (Rottemburg, 1775), Scolitantides orion (Pallas, 1771), Argynnis pandora ([Denis \& Schiffermüller], 1775) is említett, amelyek az 19861995 közötti kutatás során nem kerültek elő.

A nappali lepkék között számos védett és Natura 2000 faj van (1. táblázat). Faunisztikai és természetvédelmi szempontból is a Lycaena dispar rutilus, a Lycaena hippothoe, a Maculinea nausithous, a Maculinea teleius, a Boloria selene és a Nymphalis urticae a legjelentősebb fajok.

A 90-es évek vége után a Lycaena hippothoe, a Nymphalis urticae és a Argynnis pandora állományai eltűntek a területről. Az eltűnés magyarázatát elsősorban globális, mint lokális tényezőkkel magyarázhatjuk, mivel a jelenség a Dunántúli-dombság, és szinte hazánk egész területére igaz. A 2010-es években végzett terepi megfigyelések tapasztalatai is azt mutatják, hogy tovább csökkent a Lycaena dispar rutilus, a Maculinea nausithous, a Maculinea teleius, Natura 2000 fajok, valamint a Boloria selene állománya is. E fajok állományai a Tuskósi-rét kezelésével, kaszálásával és az elmúlt években erősen ingadozó talajvízszint ingadozásaival hozhatók összefüggésbe. A területen egyre több helyen jelentek meg özöngyomok (pl. Solidago sp.), ezzel csökkentve a természetes élőhelyek nagyságát.
Az éjszakai lepkefauna gazdag, a fénycsapdás mintavételezés és az alkalmi lámpázások során öszszesen 431 faj került elő. A fauna jellemzőit mutatja a 2 . táblázat, amelyben az 1\%-os dominancát elért fajokat soroltam fel a fénycsapda anyagok mennyisége alapján. A 2. táblázatban feltűnő, hogy rendkívül magas a párás mezoklímatikus környezetben a zuzmófogyasztó (Pelosia muscerda, Lithosia quadra, Eilema sororcula) fajok aránya. Másik jellemvonása a területnek, hogy a polifág gyepfogyasztók (Mythimna turca, Axylia putris, Ochropleura plecta, stb.) nagyobb számban voltak jelen, mint a polifág lombfogyasztók. A gyepfogyasztók közül külön kiemelendő a csalánon is fejlődő fajok (Spilarctia lutea, Spilosoma lubricipedum, Habrosyne pyritoides, Diachrysia chrysitis) magas dominanciája. A polifág lombfogyasztók között a tavasszal rajzó, a nyáron hernyóalakban tenyésző fajok (Orthosia gothica, Conistra vaccinii, Lycia hirtaria stb.) érdemelnek említést. Rendkívül magas az égert, és a nyírt fogyasztó fajok aránya, pl. az Ochropacha duplaris elérte az 1\%-os dominanciát. További gyakoribb fajok: Drepana curvatula, Falcaria lacertinaria, Acronicta cuspis, Acronicta alni, Acronicta strigosa, Acronicta leporina, Euchoeca nebulata, Aethalura punctulata, Hydraelia flammeoleria.

A kanizsabereki természetközeli élőhely karakterfajait az euro-szibériai, feltöltődési társulásokhoz (arundiphil) kötődő komponensek alkotják pl. Rhizedra lutosa, Phragmatiphila nexa, Nonagria typhae, Sedina buettneri, Eutrix potatoria. Ezek a fajok a nádasokhoz, gyékényesekhez és magassásokhoz kapcsolódnak. Hasonlóan jellegzetes a higrofil euroszibériai fajok (Mythimna pudorina, M. impura, Deltote uncula) gyakorisága.

Megtalálhatók itt az euroszibériai nyír-füz-égerláp komponensek azon fajai (pl. Pheosia gnoma, Furcula bicuspis, Drepana curvatula, Falcaria lacertinaria, Pleosia muscerda, Endromis versicolora), amelyek az alacsonyabb lápos területekhez kötődnek.

$\mathrm{Az}$ eddigi felmérések jórészt a lápterület szűkebb, üdébb környezetéhez kötődtek, de valószínű, hogy a szárazabb homoki gyepekben tenyésző fajok (Actinotia radiosa, Euxoa segnilis) előfordulása jelzi, hogy a terület diverzebb, mint ahogy azt a jelenlegi felmérés mutatja.

A lámpázások a védett területen vagy annak közvetlen környezetében voltak. Ezekben az erdőkben gyakran a domináns fajok nem is a tölgyhöz, vagy a gyepszinthez kötődnek, hanem a párás mezoklíma miatt szintén a zuzmószövő fajok (Lithosia, Eilema sp.). Emellett a polifág gyepfogyasztóknak (pl. a Xestia c-nigrum, a Mythimna turca, a Spilosoma lutea, a S. lubricipeda, az Axylia putris) is nagy egyedszámban tenyésznek itt.

A polifág lombfogyasztó fajok közül különösen a gyakoribb Orthosia, Calocasia, Pseudoips, és Conistra fajok (pl. O. gothica, O. incerta, O. stabilis, C. vaccinii) képesek nagy mennyiségben fellépni a tavaszi és az őszi aszpektusban. A nyári aszpektus rendkívül diverz, a személyes mintavételezések alkalmával - kedvező időjárási helyzetben - akár $80-100$ faj is előkerült egyetlen éjszakán a nagylepke faunából. 
1. táblázat. Természetvédelmi szempontból fontos fajok

\begin{tabular}{|c|c|c|}
\hline Fajnév & Védett faj & Natura 2000 \\
\hline Endromis versicolora & $x$ & \\
\hline Marumba quercus & $x$ & \\
\hline Proserpinus proserpina & $x$ & $x$ \\
\hline Saturnia pavonia & $\mathrm{x}$ & \\
\hline Saturnia pyri & $x$ & \\
\hline Boudinotiana notha & $x$ & \\
\hline Larentia clavaria & $x$ & \\
\hline $\begin{array}{l}\text { Chariaspilates for- } \\
\text { mosaria }\end{array}$ & $x$ & \\
\hline Furcula bicuspis & $x$ & \\
\hline Drymonia velitaris & $\mathrm{x}$ & \\
\hline Pheosia gnoma & $x$ & \\
\hline $\begin{array}{l}\text { Euplagia quadripunc- } \\
\text { taria }\end{array}$ & $x$ & $x$ \\
\hline Tyria jacobaeae & $x$ & \\
\hline Catocala fraxini & $x$ & \\
\hline Phragmatiphila nexa & $x$ & \\
\hline Apamea syriaca & $x$ & \\
\hline Pyrgus serratulae & $x$ & \\
\hline Heteropterus morpheus & $\mathrm{x}$ & \\
\hline Iphiclides podalirius & $x$ & \\
\hline Papilio machaon & $x$ & \\
\hline Gonepteryx rhamni & $x$ & \\
\hline Lycaena dispar & $\mathrm{x}$ & $x$ \\
\hline Lycaena hippothoe & $\mathrm{x}$ & \\
\hline Satyrium pruni & $x$ & \\
\hline Cupido alcetas & $\mathrm{x}$ & \\
\hline Scolitantides orion & $x$ & \\
\hline Glaucopsyche alexis & $x$ & \\
\hline Maculinea nausithous & $x$ & $x$ \\
\hline Maculinea teleius & $\mathrm{x}$ & $\mathrm{x}$ \\
\hline Aricia agestis & $\mathrm{x}$ & \\
\hline Neptis sappho & $x$ & \\
\hline Argynnis paphia & $x$ & \\
\hline Argynnis pandora & $x$ & \\
\hline Brenthis daphne & $\mathrm{x}$ & \\
\hline Boloria euphrosyne & $x$ & \\
\hline Boloria selene & $x$ & \\
\hline Apatura ilia & $x$ & \\
\hline Melitaea trivia & $x$ & \\
\hline Melitaea aurelia & $x$ & \\
\hline Nymphalis io & $x$ & \\
\hline Nymphalis urticae & $x$ & \\
\hline Nymphalis c-album & $x$ & \\
\hline Vanessa atalanta & $x$ & \\
\hline
\end{tabular}

2. táblázat. Kanizsaberekben a fénycsapdás gyüjtések során 1\%-os dominanciát elért fajok

\begin{tabular}{|l|c|}
\hline Fajnév & dominancia (\%) \\
\hline Pelosia muscerda & 862 \\
\hline Mythimna turca & 660 \\
\hline Lithosia quadra & 573 \\
\hline Spilarctia lutea & 257 \\
\hline Eilema sororcula & 255 \\
\hline Axylia putris & 226 \\
\hline Spilosoma lubricipedum & 216 \\
\hline Orthosia gothica & 164 \\
\hline Habrosyne pyritoides & 160 \\
\hline Hypena proboscidalis & 141 \\
\hline Colocasia coryli & 137 \\
\hline Phragmatobia fuliginosa & 123 \\
\hline Diacrisia sannio & 114 \\
\hline Lycia hirtaria & 106 \\
\hline Ochropleura plecta & 104 \\
\hline Ochropacha duplaris & 96 \\
\hline Pseudoips prasinana & 92 \\
\hline Diachrysia chrysitis & 83 \\
\hline Conistra (Conistra) vaccinii & 82 \\
\hline
\end{tabular}

A csak a lámpázások során ismertté vált fajok közül faunisztikai szempontból kiemelendő az Achlya flavicornis és a Geometra papilionaria jellegzetesen nyír-, vagy égerfogyasztó fajok. A Macrochilo cribrumalis, és a Laelia coenosa a Bojsza-tó melletti nádasok és sásosok gyenge röpképességű fajai. A homokhátak tetejét a látványos megjelenésü sasharasztosok foglalják el, amelynek jellemző fajai a Petrophora chlorosata és a Callopistria juventina.

A személyes lámpázások (355 faj) és a Kanizsaberekben müködtetett fénycsapda (367 faj, 8190 példány) valamint a korábbi publikált és munkajelentésben összefoglalt adatok (Kovács 1953, 1956, Ábrahám 1989, 1995, Ábrahám és Uherkovich 2001, Uherkovich 1997) szerint jelenleg összesen 504 faj (73 nappali és 431 éjszakai lepke) ismert a Baláta szűkebb környezetéből (3. táblázat). Természetvédelmi szempont a terület jelentőséget mutatja a védett fajok nagy száma, 43 védett faj és az 5 Natura 2000 faj (1. táblázat). A vizsgált terület faunája kvantitatív és kvalitatív viszonyait tekintve nagyon hasonlít az alaposabban vizsgált Barcsi-Borókás Tájvédelmi Körzet, (Uherkovich 1978, 1981, 1983), a Boronka-melléki Tájvédelmi Körzet (Ábrahám 1992) és a Dráva-vidék belső-somogyi nemzeti parki területeihez (Uherkovich és Ábrahám 1995, Ábrahám és Uherkovich 1998). 
3. táblázat: A Baláta környékéről ismert fajok listája az irodalmi adatok és a jelenlegi vizsgálat alapján

\begin{tabular}{|c|c|c|c|c|c|}
\hline Taxonok & $\begin{array}{c}\text { Kanizsaberek } \\
\text { fénycsapda és } \\
\text { nappali mintavételek }\end{array}$ & $\begin{array}{l}\text { 1. mintavételi } \\
\text { hely }\end{array}$ & $\begin{array}{l}\text { 2. mintavételi } \\
\text { hely }\end{array}$ & $\begin{array}{l}\text { 3. mintavételi } \\
\text { hely }\end{array}$ & $\begin{array}{c}\text { Irodalmi adatok } \\
\text { (Kovács 1953, Ábrahám } \\
\text { 1989, Uherkovich 1997) }\end{array}$ \\
\hline \multicolumn{6}{|l|}{ Lasiocampidae Harris, 1841} \\
\hline $\begin{array}{l}\text { Malacosoma neustria } \\
\text { (Linnaeus, 1758) }\end{array}$ & 7 & $x$ & & & \\
\hline $\begin{array}{l}\text { Euthrix potatoria } \\
\text { (Linnaeus, 1758) }\end{array}$ & 2 & $x$ & $x$ & & $x$ \\
\hline $\begin{array}{l}\text { Odonestis pruni } \\
\text { (Linnaeus, 1758) }\end{array}$ & 2 & $\mathrm{x}$ & & & \\
\hline $\begin{array}{l}\text { Lasiocampa trifolii } \\
\text { ([Denis \& Schiffermiüller], 1775) }\end{array}$ & 12 & & $x$ & $x$ & \\
\hline $\begin{array}{l}\text { Macrothylacia rubi } \\
\text { (Linnaeus, 1758) }\end{array}$ & 26 & $x$ & $\mathrm{x}$ & & $x$ \\
\hline $\begin{array}{l}\text { Dendrolimus pini } \\
\text { (Linnaeus, 1758) }\end{array}$ & 23 & $x$ & $x$ & $x$ & $x$ \\
\hline $\begin{array}{l}\text { Gastropacha quercifolia } \\
\text { (Linnaeus, 1758) }\end{array}$ & & & & & $x$ \\
\hline \multicolumn{6}{|l|}{ Endromidae Boisduval, 1828} \\
\hline $\begin{array}{l}\text { Endromis versicolora } \\
\text { (Linnaeus, 1758) }\end{array}$ & 1 & $\mathrm{x}$ & & & \\
\hline \multicolumn{6}{|l|}{ Sphingidae Latreille, [1802] } \\
\hline $\begin{array}{l}\text { Agrius convolvuli } \\
\text { (Linnaeus, 1758) }\end{array}$ & 6 & & $x$ & & \\
\hline Sphinx ligustri Linnaeus, 1758 & 1 & $x$ & & & \\
\hline $\begin{array}{l}\text { Hyloicus pinastri } \\
\text { (Linnaeus, 1758) }\end{array}$ & 38 & $x$ & $x$ & $\mathrm{x}$ & \\
\hline $\begin{array}{l}\text { Laothoe populi } \\
\text { (Linnaeus, 1758) }\end{array}$ & 21 & $x$ & $x$ & $\mathrm{x}$ & \\
\hline $\begin{array}{l}\text { Marumba quercus } \\
\text { ([Denis \& Schiffermüller], 1775) }\end{array}$ & & & & & $x$ \\
\hline $\begin{array}{l}\text { Mimas tiliae } \\
\text { (Linnaeus, 1758) }\end{array}$ & 14 & $x$ & $x$ & & $x$ \\
\hline $\begin{array}{l}\text { Smerinthus ocellatus } \\
\text { (Linnaeus, 1758) }\end{array}$ & 8 & $\mathrm{x}$ & $\mathrm{x}$ & & $x$ \\
\hline $\begin{array}{l}\text { Proserpinus proserpina } \\
\text { (Pallas, 1772) }\end{array}$ & 1 & $x$ & & & \\
\hline $\begin{array}{l}\text { Deilephila elpenor } \\
\text { (Linnaeus, 1758) }\end{array}$ & 28 & $x$ & $\mathrm{x}$ & $x$ & \\
\hline $\begin{array}{l}\text { Deilephila porcellus } \\
\text { (Linnaeus, 1758) }\end{array}$ & 51 & $x$ & $x$ & & \\
\hline $\begin{array}{l}\text { Hyles euphorbiae } \\
\text { (Linnaeus, 1758) }\end{array}$ & 2 & $\mathrm{x}$ & & & \\
\hline \multicolumn{6}{|l|}{$\begin{array}{l}\text { Saturniidae Boisduval, } \\
\text { [1837] } 1834\end{array}$} \\
\hline $\begin{array}{l}\text { Antherea yantamai } \\
\text { Guerin-Meneville, } 1861\end{array}$ & 5 & $x$ & $x$ & $x$ & \\
\hline $\begin{array}{l}\text { Saturnia pavoniella } \\
\text { (Scopoli, 1763) }\end{array}$ & 6 & & $x$ & & \\
\hline $\begin{array}{l}\text { Saturnia pyri } \\
\text { ([Denis \& Schiffermüller], } 1775\end{array}$ & 2 & $x$ & & & \\
\hline \multicolumn{6}{|l|}{ Drepanidae Meyrick, 1895} \\
\hline $\begin{array}{l}\text { Cilix glaucata } \\
\text { (Scopoli, 1763) }\end{array}$ & 6 & $x$ & $x$ & $x$ & \\
\hline $\begin{array}{l}\text { Drepana curvatula } \\
\text { (Borkhausen, 1790) }\end{array}$ & 23 & $\mathrm{x}$ & $x$ & $\mathrm{x}$ & $x$ \\
\hline $\begin{array}{l}\text { Drepana falcataria } \\
\text { (Linnaeus, 1758) }\end{array}$ & 47 & $x$ & $x$ & $x$ & $x$ \\
\hline $\begin{array}{l}\text { Falcaria lacertinaria } \\
\text { (Linnaeus, 1758) }\end{array}$ & 5 & $x$ & $x$ & $\mathrm{x}$ & $x$ \\
\hline $\begin{array}{l}\text { Sabra harpagula } \\
\text { (Esper, 1786) }\end{array}$ & 10 & $x$ & $x$ & & \\
\hline
\end{tabular}




\begin{tabular}{|c|c|c|c|c|c|}
\hline Taxonok & $\begin{array}{c}\text { Kanizsaberek } \\
\text { fénycsapda és } \\
\text { nappali mintavételek }\end{array}$ & $\begin{array}{l}\text { 1. mintavételi } \\
\text { hely }\end{array}$ & $\begin{array}{l}\text { 2. mintavételi } \\
\text { hely }\end{array}$ & $\begin{array}{l}\text { 3. mintavételi } \\
\text { hely }\end{array}$ & $\begin{array}{c}\text { Irodalmi adatok (Kovács } \\
\text { 1953, Ábrahám 1989, } \\
\text { Uherkovich 1997) }\end{array}$ \\
\hline $\begin{array}{l}\text { Watsonalla binaria } \\
\text { (Hufnagel, 1766) }\end{array}$ & 11 & $\mathrm{x}$ & $\mathrm{x}$ & & \\
\hline $\begin{array}{l}\text { Watsonalla cultraria } \\
\text { (Fabricius, 1775) }\end{array}$ & 1 & & $\mathrm{x}$ & & \\
\hline Thyatiridae Smith, 1893 & & & & & $x$ \\
\hline $\begin{array}{l}\text { Thyatira batis } \\
\text { (Linnaeus, 1758) }\end{array}$ & 45 & $x$ & $x$ & $x$ & $x$ \\
\hline $\begin{array}{l}\text { Tetltea ocularis } \\
\text { (Linnaeus, 1767) }\end{array}$ & 2 & $x$ & $\mathrm{x}$ & & \\
\hline $\begin{array}{l}\text { Tethea or } \\
\text { ([Denis \& Schiffermüller], 1775) }\end{array}$ & 4 & $\mathrm{x}$ & $\mathrm{x}$ & $\mathrm{x}$ & \\
\hline $\begin{array}{l}\text { Ochropacha duplaris } \\
\text { (Linnaeus, 1761) }\end{array}$ & 96 & $\mathrm{x}$ & $\mathrm{x}$ & $\mathrm{x}$ & $\mathrm{x}$ \\
\hline $\begin{array}{l}\text { Habrosyne pyritoides } \\
\text { (Hufnagel, 1766) }\end{array}$ & 160 & $\mathrm{x}$ & $x$ & $x$ & $\mathrm{x}$ \\
\hline $\begin{array}{l}\text { Polyploca ridens } \\
\text { (Fabricius, 1787) }\end{array}$ & 2 & & $\mathrm{x}$ & & $\mathrm{x}$ \\
\hline $\begin{array}{l}\text { Achlya flavicornis } \\
\text { (Linnaeus, 1758) }\end{array}$ & & & & $\mathrm{x}$ & \\
\hline $\begin{array}{l}\text { Asphalia ruficollis } \\
\text { ([Denis \& Schiffermüller], 1775) }\end{array}$ & & & & & \\
\hline \multicolumn{6}{|l|}{ Geometridae Leach, [1815] } \\
\hline $\begin{array}{l}\text { Boudinotiana notha } \\
\text { (Hübner, 1803) }\end{array}$ & & & & & $\mathrm{x}$ \\
\hline $\begin{array}{l}\text { Alsophila aescularia } \\
\text { ([Denis \& Schiffermüller], 1775) }\end{array}$ & & & & $\mathrm{x}$ & $\mathrm{x}$ \\
\hline $\begin{array}{l}\text { Geometra papilionaria } \\
\text { (Linnaeus, 1758) }\end{array}$ & & & & $\mathrm{x}$ & $\mathrm{x}$ \\
\hline $\begin{array}{l}\text { Cotnibaena bajularia } \\
\text { ([Denis \& Schiffermüller], 1775) }\end{array}$ & 23 & $\mathrm{x}$ & $\mathrm{x}$ & $x$ & \\
\hline $\begin{array}{l}\text { Thetidia smaragdaria } \\
\text { (Fabricius, 1787) }\end{array}$ & 1 & & & & \\
\hline $\begin{array}{l}\text { Hemistola chrysoprasaria } \\
\text { (Esper, 1795) }\end{array}$ & 3 & $\mathrm{x}$ & & & \\
\hline $\begin{array}{l}\text { Thalera fimbrialis } \\
\text { (Scopoli, 1763) }\end{array}$ & 12 & $\mathrm{x}$ & & $\mathrm{x}$ & \\
\hline $\begin{array}{l}\text { Hemithea aestivaria } \\
\text { (Hübner, 1789) }\end{array}$ & 14 & $x$ & $\mathrm{x}$ & & $x$ \\
\hline $\begin{array}{l}\text { Chlorissa cloraria } \\
\text { (Hübner, [1813]) }\end{array}$ & 2 & $x$ & & & \\
\hline $\begin{array}{l}\text { Idaea muricata } \\
\text { (Hufnagel, 1767) }\end{array}$ & 6 & & $x$ & $\mathrm{x}$ & $\mathrm{x}$ \\
\hline $\begin{array}{l}\text { Idaea ochrata } \\
\text { (Scopoli, 1763) }\end{array}$ & 2 & $\mathrm{x}$ & & $\mathrm{x}$ & $\mathrm{x}$ \\
\hline $\begin{array}{l}\text { Idaea humiliata } \\
\text { (Hufnagel, 1767) }\end{array}$ & 1 & $\mathrm{x}$ & & & \\
\hline $\begin{array}{l}\text { Idaea subsericeata } \\
\text { (Haworth, 1809) }\end{array}$ & 2 & & $\mathrm{x}$ & & \\
\hline $\begin{array}{l}\text { Idaea dimidiata } \\
\text { (Hufnagel, 1767) }\end{array}$ & 8 & & $\mathrm{x}$ & $\mathrm{x}$ & \\
\hline $\begin{array}{l}\text { Idaea politaria } \\
\text { (Hübner, 1799) }\end{array}$ & & & & & $\mathrm{x}$ \\
\hline $\begin{array}{l}\text { Idaea trigeminata } \\
\text { (Haworth, 1809) }\end{array}$ & 1 & & & $\mathrm{x}$ & \\
\hline $\begin{array}{l}\text { Idaea biselata } \\
\text { (Hufnagel, 1767) }\end{array}$ & 1 & $\mathrm{x}$ & & & \\
\hline $\begin{array}{l}\text { Idaea emarginata } \\
\text { (Linnaeus, } 1758\end{array}$ & 1 & & & & \\
\hline $\begin{array}{l}\text { Idaea rubraria } \\
\text { (Staudinger, 1901) }\end{array}$ & & & & $\mathrm{x}$ & $\mathrm{x}$ \\
\hline $\begin{array}{l}\text { Idaea aversata } \\
\text { (Linnaeus, 1758) }\end{array}$ & 21 & $\mathrm{x}$ & $\mathrm{x}$ & & $\mathrm{x}$ \\
\hline $\begin{array}{l}\text { Idaea deversaria } \\
\text { (Herrich-Schaffer, 1847) }\end{array}$ & 2 & & & & \\
\hline
\end{tabular}


TERMÉSZETVÉDELMI TERÜLETEN

\begin{tabular}{|c|c|c|c|c|c|}
\hline Taxonok & $\begin{array}{c}\text { Kanizsaberek } \\
\text { fénycsapda és } \\
\text { nappali mintavételek }\end{array}$ & $\begin{array}{l}\text { 1. mintavételi } \\
\text { hely }\end{array}$ & $\begin{array}{l}\text { 2. mintavételi } \\
\text { hely }\end{array}$ & $\begin{array}{l}\text { 3. mintavételi } \\
\text { hely }\end{array}$ & $\begin{array}{c}\text { Irodalmi adatok (Kovács } \\
\text { 1953, Ábrahám 1989, } \\
\text { Uherkovich 1997) }\end{array}$ \\
\hline $\begin{array}{l}\text { Scopula immorata } \\
\text { (Linnaeus, 1758) }\end{array}$ & 19 & $x$ & $x$ & & \\
\hline $\begin{array}{l}\text { Scopula corrivalaria } \\
\text { (Kretschmar, 1862) }\end{array}$ & 3 & $x$ & & & $\mathrm{x}$ \\
\hline $\begin{array}{l}\text { Scopula nigropunctata } \\
\text { (Hufnagel, 1767) }\end{array}$ & 2 & & & & $x$ \\
\hline $\begin{array}{l}\text { Scopula virgulata } \\
\text { ([Denis \& Schiffermüller], 1775) }\end{array}$ & 4 & $x$ & $x$ & & \\
\hline $\begin{array}{l}\text { Scopula ornata } \\
\text { (Scopoli, 1763) }\end{array}$ & 2 & & $\mathrm{x}$ & & \\
\hline $\begin{array}{l}\text { Scopula rubiginata } \\
\text { (Hufnagel, 1767) }\end{array}$ & 1 & & $x$ & & \\
\hline $\begin{array}{l}\text { Scopula immutata } \\
\text { (Linnaeus, 1758) }\end{array}$ & 6 & $x$ & & & $x$ \\
\hline $\begin{array}{l}\text { Scopula flaccidaria } \\
\text { (Zeller, 1852) }\end{array}$ & 1 & & & & \\
\hline Timandra comae Schmidt, 1931 & 24 & $x$ & $x$ & $x$ & $x$ \\
\hline $\begin{array}{l}\text { Cyclophora pendularia } \\
\text { (Clerck, 1759) }\end{array}$ & 1 & & & $\mathrm{x}$ & $\mathrm{x}$ \\
\hline $\begin{array}{l}\text { Cyclophora albipunctata } \\
\text { (Hufnagel, 1767) }\end{array}$ & 1 & & $x$ & & $x$ \\
\hline $\begin{array}{l}\text { Cyclophora albiocellaria } \\
\text { (Hübner, 1789) }\end{array}$ & 2 & & $x$ & $x$ & \\
\hline $\begin{array}{l}\text { Cyclophora annularia } \\
\text { (Fabricius, 1775) }\end{array}$ & 3 & $x$ & $x$ & & $x$ \\
\hline $\begin{array}{l}\text { Cyclophora ruficiliaria } \\
\text { (Herrich-Schaffer, 1855) }\end{array}$ & 1 & $x$ & & & $x$ \\
\hline $\begin{array}{l}\text { Cyclophora quercimontaria } \\
\text { (Bastelberger, 1897) }\end{array}$ & & & & & $x$ \\
\hline $\begin{array}{l}\text { Cyclophora porata } \\
\text { (Linnaeus, 1767) }\end{array}$ & & & & $\mathrm{x}$ & \\
\hline $\begin{array}{l}\text { Cyclophora punctaria } \\
\text { (Linnaeus, 1758) }\end{array}$ & 11 & $x$ & $x$ & $x$ & $\mathrm{x}$ \\
\hline $\begin{array}{l}\text { Cyclophora linearia } \\
\text { (Hübner, 1799) }\end{array}$ & 3 & $x$ & $\mathrm{x}$ & $x$ & \\
\hline $\begin{array}{l}\text { Lythria purpuraria } \\
\text { (Linnaeus, 1758) }\end{array}$ & & & & $x$ & \\
\hline $\begin{array}{l}\text { Orthonama obstipata } \\
\text { (Fabricius, 1794) }\end{array}$ & 2 & & & & \\
\hline $\begin{array}{l}\text { Xanthorhoe biriviata } \\
\text { (Borkhausen, 1794) }\end{array}$ & 3 & & $x$ & $x$ & $x$ \\
\hline $\begin{array}{l}\text { Xanthorhoe designata } \\
\text { (Hufnagel, 1767) }\end{array}$ & 1 & & $x$ & $x$ & \\
\hline $\begin{array}{l}\text { Xanthorhoe spadicearia } \\
\text { ([Denis \& Schiffermüller], 1775) }\end{array}$ & 3 & $x$ & & $x$ & $x$ \\
\hline $\begin{array}{l}\text { Xanthorhoe ferrugata } \\
\text { (Clerck, 1759) }\end{array}$ & 16 & $x$ & $x$ & $\mathrm{x}$ & $x$ \\
\hline $\begin{array}{l}\text { Xanthorhoe quadrifasiata } \\
\text { (Clerck, 1759) }\end{array}$ & 1 & $x$ & & $x$ & \\
\hline $\begin{array}{l}\text { Catarhoe rubidata } \\
\text { ([De nis \& Schiffermüller], 1775) }\end{array}$ & & & & $x$ & \\
\hline $\begin{array}{l}\text { Catarhoe cuculata } \\
\text { (Hufnagel, 1767) }\end{array}$ & 4 & $x$ & & $x$ & \\
\hline $\begin{array}{l}\text { Epirrhoe tristata } \\
\text { (Linnaeus, 1758) }\end{array}$ & 1 & & $x$ & & \\
\hline $\begin{array}{l}\text { Epirrhoe alternata } \\
\text { (Müller, 1764) }\end{array}$ & 33 & $x$ & $x$ & $x$ & $x$ \\
\hline $\begin{array}{l}\text { Epirrhoe rivata } \\
\text { (Hübner, 1813) }\end{array}$ & & & & $x$ & \\
\hline $\begin{array}{l}\text { Epirrhoe galiata } \\
\text { ([Denis \& Schiffermüller], 1775) }\end{array}$ & 1 & $\mathrm{x}$ & & & $\mathrm{x}$ \\
\hline $\begin{array}{l}\text { Euphya biangulata } \\
\text { (Haworth, 1809) }\end{array}$ & & & & $x$ & \\
\hline $\begin{array}{l}\text { Euphya unangulata } \\
\text { (Haworth, 1809) }\end{array}$ & 18 & $x$ & $x$ & $\mathrm{x}$ & $\mathrm{x}$ \\
\hline
\end{tabular}




\begin{tabular}{|c|c|c|c|c|c|}
\hline Taxonok & $\begin{array}{c}\text { Kanizsaberek } \\
\text { fénycsapda és } \\
\text { nappali mintavételek }\end{array}$ & $\begin{array}{l}\text { 1. mintavételi } \\
\text { hely }\end{array}$ & $\begin{array}{l}\text { 2. mintavételi } \\
\text { hely }\end{array}$ & $\begin{array}{l}\text { 3. mintavételi } \\
\text { hely }\end{array}$ & $\begin{array}{c}\text { Irodalmi adatok } \\
\text { (Kovács 1953, Ábrahám } \\
\text { 1989, Uherkovich 1997) }\end{array}$ \\
\hline $\begin{array}{l}\text { Costaconvexa polygrammata } \\
\text { (Borkhausen, 1794) }\end{array}$ & 2 & $x$ & $x$ & & \\
\hline $\begin{array}{l}\text { Larentia clavaria } \\
\text { (Haworth, 1809) }\end{array}$ & 1 & & & & $x$ \\
\hline $\begin{array}{l}\text { Mesoleuca albicillata } \\
\text { (Linnaeus, 1758) }\end{array}$ & & & & $\mathrm{x}$ & $x$ \\
\hline $\begin{array}{l}\text { Lampropteryx suffumata } \\
\text { ([Denis \& Schiffermüller], 1775) }\end{array}$ & 1 & $x$ & & $x$ & \\
\hline $\begin{array}{l}\text { Cosmorhoe ocellata } \\
\text { (Linnaeus, 1758) }\end{array}$ & 2 & $x$ & $x$ & $x$ & \\
\hline $\begin{array}{l}\text { Eulithis mellinata } \\
\text { (Fabricius, 1787) }\end{array}$ & & $x$ & & & \\
\hline $\begin{array}{l}\text { Eulithis pyraliata } \\
\text { ([Denis \& Schiffermüller], 1775) }\end{array}$ & 1 & & & $x$ & $\mathrm{x}$ \\
\hline $\begin{array}{l}\text { Ecliptopera silaceata } \\
\text { ([Denis \& Schiffermüller], 1775) }\end{array}$ & 19 & & & $x$ & $x$ \\
\hline $\begin{array}{l}\text { Ecliptoptera capitata } \\
\text { (Herrich-Schaffer, 1839) }\end{array}$ & & & & & $x$ \\
\hline $\begin{array}{l}\text { Pennithera firmata } \\
\text { (Hübner, 1822) }\end{array}$ & 1 & & & $x$ & \\
\hline $\begin{array}{l}\text { Thera variata } \\
\text { ([Denis \& Schiffermüller], 1775) }\end{array}$ & 3 & $\mathrm{x}$ & $\mathrm{x}$ & & \\
\hline $\begin{array}{l}\text { Colostygia pectinataria } \\
\text { (Knoch, 1781) }\end{array}$ & 6 & $x$ & $\mathrm{x}$ & $x$ & $\mathrm{x}$ \\
\hline $\begin{array}{l}\text { Hydriomena furcata } \\
\text { (Thunberg, 1784) }\end{array}$ & 1 & $x$ & & $x$ & \\
\hline $\begin{array}{l}\text { Hydriomena impluviata } \\
\text { ([Denis \& Schiffermüller], 1775) }\end{array}$ & 4 & & & $x$ & $x$ \\
\hline $\begin{array}{l}\text { Melanthia procellata } \\
\text { ([Denis \& Schiffermiüller], 1775) }\end{array}$ & 1 & & & & $\mathrm{x}$ \\
\hline $\begin{array}{l}\text { Anticollix sparsata } \\
\text { (Treitschke, 1828) }\end{array}$ & & & & & $x$ \\
\hline $\begin{array}{l}\text { Philereme vetulata } \\
\text { ([Denis \& Schiffermüller], 1775) }\end{array}$ & 2 & & & & \\
\hline $\begin{array}{l}\text { Operophtera fagata } \\
\text { (Scharfenberg, 1805) }\end{array}$ & 1 & & & & \\
\hline $\begin{array}{l}\text { Perizoma alchemillata } \\
\text { (Linnaeus, 1758) }\end{array}$ & 12 & & $x$ & $x$ & $x$ \\
\hline $\begin{array}{l}\text { Perizoma lugdunaria } \\
\text { (Herrich-Schaffer, 1855) }\end{array}$ & & & & $x$ & \\
\hline $\begin{array}{l}\text { Perizoma bifaciata } \\
\text { (Haworth, 1809) }\end{array}$ & & & & $x$ & \\
\hline $\begin{array}{l}\text { Perizonta flavofasciata } \\
\text { (Thunberg, 1792) }\end{array}$ & 1 & $x$ & & $x$ & \\
\hline $\begin{array}{l}\text { Gymnoscelis rufifasciata } \\
\text { (Haworth, 1809) }\end{array}$ & 1 & & & $x$ & \\
\hline $\begin{array}{l}\text { Chloroclystis v-ata } \\
\text { (Haworth, 1809) }\end{array}$ & & & & $x$ & $x$ \\
\hline $\begin{array}{l}\text { Pasiphila rectangulata } \\
\text { (Linnaeus, 1758) }\end{array}$ & & & & & $x$ \\
\hline $\begin{array}{l}\text { Pasiphila debiliata } \\
\text { (Hübner, 1817) }\end{array}$ & & & & $x$ & \\
\hline $\begin{array}{l}\text { Eupithecia haworthiata } \\
\text { Doubleday, } 1856\end{array}$ & & & & $x$ & \\
\hline $\begin{array}{l}\text { Eupithecia inturbata } \\
\text { (Hübner, 1817) }\end{array}$ & 2 & $\mathrm{x}$ & & & \\
\hline $\begin{array}{l}\text { Eupithecia linariata } \\
\text { ([Denis \& Schiffermüller], 1775) }\end{array}$ & & & & $x$ & \\
\hline $\begin{array}{l}\text { Eupithecia pyreneata } \\
\text { Mabille, } 1871\end{array}$ & & & & & $x$ \\
\hline $\begin{array}{l}\text { Eulithis mellinata } \\
\text { (Fabricius, 1787) }\end{array}$ & & $x$ & & & \\
\hline $\begin{array}{l}\text { Eulithis pyraliata } \\
\text { ([Denis \& Schiffermüller], 1775) }\end{array}$ & 1 & & & $x$ & $x$ \\
\hline $\begin{array}{l}\text { Ecliptopera silaceata } \\
\text { ([Denis \& Schiffermüller], 1775) }\end{array}$ & 19 & & & $x$ & $x$ \\
\hline
\end{tabular}




\begin{tabular}{|c|c|c|c|c|c|}
\hline Taxonok & $\begin{array}{c}\text { Kanizsaberek } \\
\text { fénycsapda és } \\
\text { nappali mintavételek }\end{array}$ & $\begin{array}{l}\text { 1. mintavételi } \\
\text { hely }\end{array}$ & $\begin{array}{l}\text { 2. mintavételi } \\
\text { hely }\end{array}$ & $\begin{array}{l}\text { 3. mintavételi } \\
\text { hely }\end{array}$ & $\begin{array}{c}\text { Irodalmi adatok (Kovács } \\
\text { 1953, Ábrahám 1989, } \\
\text { Uherkovich 1997) }\end{array}$ \\
\hline $\begin{array}{l}\text { Ecliptoptera capitata } \\
\text { (Herrich-Schaffer, 1839) }\end{array}$ & & & & & $x$ \\
\hline $\begin{array}{l}\text { Pennithera firmata } \\
\text { (Hübner, 1822) }\end{array}$ & 1 & & & $x$ & \\
\hline $\begin{array}{l}\text { Thera variata } \\
\text { ([Denis \& Schiffermüller], 1775) }\end{array}$ & 3 & $x$ & $x$ & & \\
\hline $\begin{array}{l}\text { Colostygia pectinataria } \\
\text { (Knoch, 1781) }\end{array}$ & 6 & $x$ & $x$ & $x$ & $x$ \\
\hline $\begin{array}{l}\text { Hydriomena furcata } \\
\text { (Thunberg, 1784) }\end{array}$ & 1 & $x$ & & $x$ & \\
\hline $\begin{array}{l}\text { Hydriomena impluviata } \\
\text { ([Denis \& Schiffermüller], 1775) }\end{array}$ & 4 & & & $x$ & $x$ \\
\hline $\begin{array}{l}\text { Melanthia procellata } \\
\text { ([Denis \& Schiffermiüller], 1775) }\end{array}$ & 1 & & & & $x$ \\
\hline $\begin{array}{l}\text { Anticollix sparsata } \\
\text { (Treitschke, 1828) }\end{array}$ & & & & & $x$ \\
\hline $\begin{array}{l}\text { Philereme vetulata } \\
\text { ([Denis \& Schiffermüller], 1775) }\end{array}$ & 2 & & & & \\
\hline $\begin{array}{l}\text { Operophtera fagata } \\
\text { (Scharfenberg, 1805) }\end{array}$ & 1 & & & & \\
\hline $\begin{array}{l}\text { Perizoma alchemillata } \\
\text { (Linnaeus, 1758) }\end{array}$ & 12 & & $x$ & $x$ & $x$ \\
\hline $\begin{array}{l}\text { Perizoma lugdunaria } \\
\text { (Herrich-Schaffer, 1855) }\end{array}$ & & & & $x$ & \\
\hline $\begin{array}{l}\text { Perizoma bifaciata } \\
\text { (Haworth, 1809) }\end{array}$ & & & & $x$ & \\
\hline $\begin{array}{l}\text { Perizonta flavofasciata } \\
\text { (Thunberg, 1792) }\end{array}$ & 1 & $x$ & & $x$ & \\
\hline $\begin{array}{l}\text { Gymnoscelis rufifasciata } \\
\text { (Haworth, 1809) }\end{array}$ & 1 & & & $x$ & \\
\hline $\begin{array}{l}\text { Chloroclystis v-ata } \\
\text { (Haworth, 1809) }\end{array}$ & & & & $x$ & $x$ \\
\hline $\begin{array}{l}\text { Pasiphila rectangulata } \\
\text { (Linnaeus, 1758) }\end{array}$ & & & & & $x$ \\
\hline $\begin{array}{l}\text { Pasiphila debiliata } \\
\text { (Hübner, 1817) }\end{array}$ & & & & $x$ & \\
\hline $\begin{array}{l}\text { Eupithecia haworthiata } \\
\text { Doubleday, } 1856\end{array}$ & & & & $x$ & \\
\hline $\begin{array}{l}\text { Eupithecia inturbata } \\
\text { (Hübner, 1817) }\end{array}$ & 2 & $x$ & & & \\
\hline $\begin{array}{l}\text { Eupithecia linariata } \\
\text { ([Denis \& Schiffermüller], 1775) }\end{array}$ & & & & $x$ & \\
\hline $\begin{array}{l}\text { Eupithecia pyreneata } \\
\text { Mabille, } 1871\end{array}$ & & & & & $x$ \\
\hline $\begin{array}{l}\text { Eupithecia plumbeolata } \\
\text { (Haworth, 1809) }\end{array}$ & 2 & $x$ & & & \\
\hline $\begin{array}{l}\text { Eupithecia pygmaeata } \\
\text { (Hübner, 1799) }\end{array}$ & & & & & $x$ \\
\hline $\begin{array}{l}\text { Eupithecia abbreviata } \\
\text { Stephens, } 1831\end{array}$ & & & & $x$ & \\
\hline $\begin{array}{l}\text { Eupithecia dodoneata } \\
\text { Guenee, } 1858\end{array}$ & 3 & $x$ & $x$ & & \\
\hline $\begin{array}{l}\text { Eupithecia tripunctaria } \\
\text { Herrich-Schaffer, } 1852\end{array}$ & 1 & & & $x$ & $x$ \\
\hline $\begin{array}{l}\text { Eupithecia tantillaria } \\
\text { Boisduval, } 1840\end{array}$ & 1 & & $x$ & & \\
\hline $\begin{array}{l}\text { Eupithecia absinthiata } \\
\text { (Clerck, 1759) }\end{array}$ & & & & $x$ & \\
\hline $\begin{array}{l}\text { Eupithecia assimilata } \\
\text { Doubleday, } 1856\end{array}$ & 1 & & $x$ & $x$ & $x$ \\
\hline $\begin{array}{l}\text { Eupithecia vulgata } \\
\text { (Haworth, 1809) }\end{array}$ & 3 & & $x$ & & \\
\hline $\begin{array}{l}\text { Eupithecia subfuscata } \\
\text { (Haworth, 1809) }\end{array}$ & 2 & & & & \\
\hline
\end{tabular}




\begin{tabular}{|c|c|c|c|c|c|}
\hline Taxonok & $\begin{array}{c}\text { Kanizsaberek } \\
\text { fénycsapda és } \\
\text { nappali mintavételek }\end{array}$ & $\begin{array}{l}\text { 1. mintavételi } \\
\text { hely }\end{array}$ & $\begin{array}{l}\text { 2. mintavételi } \\
\text { hely }\end{array}$ & $\begin{array}{l}\text { 3. mintavételi } \\
\text { hely }\end{array}$ & $\begin{array}{c}\text { Irodalmi adatok (Kovács } \\
\text { 1953, Ábrahám 1989, } \\
\text { Uherkovich 1997) }\end{array}$ \\
\hline $\begin{array}{l}\text { Aplocera efformata } \\
\text { (Guenee, 1857) }\end{array}$ & 2 & & $x$ & & \\
\hline $\begin{array}{l}\text { Euchoeca nebulata } \\
\text { (Scopoli, 1763) }\end{array}$ & 44 & $x$ & $x$ & $x$ & \\
\hline $\begin{array}{l}\text { Asthena albulata } \\
\text { (Hufnagel, 1767) }\end{array}$ & 10 & $x$ & $x$ & $x$ & $x$ \\
\hline $\begin{array}{l}\text { Asthena anseraria } \\
\text { (Herrich-Schaffer, 1855) }\end{array}$ & & & & & $x$ \\
\hline $\begin{array}{l}\text { Hydrelia flammeolaria } \\
\text { (Hufnagel, 1767) }\end{array}$ & 47 & $x$ & & $x$ & $\mathrm{x}$ \\
\hline $\begin{array}{l}\text { Pterapherapteryx sexalata } \\
\text { (Retzius, 1783) }\end{array}$ & 2 & & & & \\
\hline $\begin{array}{l}\text { Nothocasis sertata } \\
\text { (Hübner, 1817) }\end{array}$ & & & & $x$ & \\
\hline $\begin{array}{l}\text { Acasis viretata } \\
\text { (Hübner, 1799) }\end{array}$ & & & & $x$ & \\
\hline $\begin{array}{l}\text { Abraxas grossulariata } \\
\text { (Linnaeus, 1758) }\end{array}$ & 1 & $x$ & & & $\mathrm{x}$ \\
\hline $\begin{array}{l}\text { Lomaspilis marginata } \\
\text { (Linnaeus, 1758) }\end{array}$ & 72 & $x$ & $x$ & $x$ & $x$ \\
\hline $\begin{array}{l}\text { Ligdia adustata } \\
\text { ([Denis \& Schiffermüller], 1775) }\end{array}$ & 5 & $x$ & $x$ & $x$ & $x$ \\
\hline $\begin{array}{l}\text { Macaria notata } \\
\text { (Linnaeus, 1758) }\end{array}$ & 4 & $x$ & & & \\
\hline $\begin{array}{l}\text { Macaria alternata } \\
\text { ([Denis \& Schiffermüller], 1775) }\end{array}$ & 54 & $x$ & $x$ & $x$ & $x$ \\
\hline $\begin{array}{l}\text { Macaria liturata } \\
\text { (Clerck, 1759) }\end{array}$ & 1 & & & & \\
\hline $\begin{array}{l}\text { Chiasmia clathrata } \\
\text { (Linnaeus, 1758) }\end{array}$ & 4 & $x$ & $x$ & & $x$ \\
\hline $\begin{array}{l}\text { Cepphis advenaria } \\
\text { (Hübner, 1790) }\end{array}$ & & & & $x$ & $x$ \\
\hline $\begin{array}{l}\text { Petrophora chlorosata } \\
\text { (Scopoli, 1763) }\end{array}$ & & & & $x$ & $x$ \\
\hline $\begin{array}{l}\text { Plagodis pulveraria } \\
\text { (Linnaeus, 1758) }\end{array}$ & 4 & $x$ & & $x$ & \\
\hline $\begin{array}{l}\text { Plagodis dolabraria } \\
\text { (Linnaeus, 1767) }\end{array}$ & 1 & & $x$ & $x$ & \\
\hline $\begin{array}{l}\text { Opisthograptis luteolata } \\
\text { (Linnaeus, 1758) }\end{array}$ & 1 & & & & \\
\hline $\begin{array}{l}\text { Epione repandaria } \\
\text { (Hufnagel, 1767) }\end{array}$ & 1 & & & & $x$ \\
\hline $\begin{array}{l}\text { Epione vespertaria } \\
\text { (Linnaeus, 1767) }\end{array}$ & 1 & & & & \\
\hline $\begin{array}{l}\text { Hypoxystis pluviaria } \\
\text { (Fabricius, 1787) }\end{array}$ & 9 & & $\mathrm{x}$ & & $x$ \\
\hline $\begin{array}{l}\text { Ennomos fuscantaria } \\
\text { (Haworth, 1809) }\end{array}$ & 1 & & & & \\
\hline $\begin{array}{l}\text { Ennomos erosaria } \\
\text { ([Denis \& Schiffermüller], 1775) }\end{array}$ & 1 & & & & $x$ \\
\hline $\begin{array}{l}\text { Selenia dentaria } \\
\text { (Fabricius, 1775) }\end{array}$ & 2 & $x$ & $x$ & $x$ & \\
\hline $\begin{array}{l}\text { Selenia tetralunaria } \\
\text { (Hufnagel, 1767) }\end{array}$ & 4 & $x$ & $x$ & $x$ & \\
\hline $\begin{array}{l}\text { Ourapteryx sambucaria } \\
\text { (Linnaeus, 1758) }\end{array}$ & 1 & $x$ & & & \\
\hline $\begin{array}{l}\text { Colotois pennaria } \\
\text { (Linnaeus, 1761) }\end{array}$ & 1 & & & & \\
\hline $\begin{array}{l}\text { Angerona prunaria } \\
\text { (Linnaeus, 1758) }\end{array}$ & 8 & $x$ & $x$ & $x$ & $x$ \\
\hline $\begin{array}{l}\text { Apocheima hispidaria } \\
\text { ([Denis \& Schiffermüller], 1775) }\end{array}$ & 2 & $x$ & & & \\
\hline
\end{tabular}




\begin{tabular}{|c|c|c|c|c|c|}
\hline Taxonok & $\begin{array}{c}\text { Kanizsaberek } \\
\text { fénycsapda és } \\
\text { nappali mintavételek }\end{array}$ & $\begin{array}{l}\text { 1. mintavételi } \\
\text { hely }\end{array}$ & $\begin{array}{l}\text { 2. mintavételi } \\
\text { hely }\end{array}$ & $\begin{array}{l}\text { 3. mintavételi } \\
\text { hely }\end{array}$ & $\begin{array}{c}\text { Irodalmi adatok (Kovács } \\
\text { 1953, Ábrahám 1989, } \\
\text { Uherkovich 1997) }\end{array}$ \\
\hline $\begin{array}{l}\text { Lycia hirtaria } \\
\text { (Clerck, 1759) }\end{array}$ & 106 & $x$ & $x$ & $x$ & $x$ \\
\hline $\begin{array}{l}\text { Biston strataria } \\
\text { (Hufnagel, 1767) }\end{array}$ & 1 & $x$ & & $x$ & \\
\hline $\begin{array}{l}\text { Biston betularia } \\
\text { (Linnaeus, 1758) }\end{array}$ & 14 & $x$ & $x$ & & \\
\hline $\begin{array}{l}\text { Erannis defoliaria } \\
\text { (Clerck, 1759) }\end{array}$ & 1 & & & & $x$ \\
\hline $\begin{array}{l}\text { Peribatodes rhomboidaria } \\
\text { ([Denis \& Schiffermüller], 1775) }\end{array}$ & 22 & $x$ & $x$ & $x$ & $x$ \\
\hline $\begin{array}{l}\text { Cleora cinctaria } \\
\text { ([Denis \& Schiffermüller], 1775) }\end{array}$ & 3 & $x$ & $x$ & & \\
\hline $\begin{array}{l}\text { Alcis repandata } \\
\text { (Linnaeus, 1758) }\end{array}$ & & & & $x$ & \\
\hline $\begin{array}{l}\text { Hypomecis roboraria } \\
\text { ([Denis \& Schiffermüller], 1775) }\end{array}$ & 20 & $x$ & $x$ & $x$ & $x$ \\
\hline $\begin{array}{l}\text { Hypomecis danieli } \\
\text { (Wehrli, 1932) }\end{array}$ & & & & & $x$ \\
\hline $\begin{array}{l}\text { Hypomecis punctinalis } \\
\text { (Scopoli, 1763) }\end{array}$ & 42 & $x$ & $x$ & $x$ & $x$ \\
\hline $\begin{array}{l}\text { Cleorodes lichenaria } \\
\text { (Hufnagel, 1767) }\end{array}$ & & & & & $x$ \\
\hline $\begin{array}{l}\text { Fagivorina arenaria } \\
\text { (Hufnagel, 1767) }\end{array}$ & & $x$ & $x$ & $x$ & \\
\hline $\begin{array}{l}\text { Ascotis selenaria } \\
\text { ([Denis \& Schiffermüller], 1775) }\end{array}$ & 11 & & & $x$ & \\
\hline $\begin{array}{l}\text { Ectropis crepuscularia } \\
\text { ([Denis \& Schiffermüller], 1775) }\end{array}$ & 3 & $x$ & $x$ & $x$ & $x$ \\
\hline $\begin{array}{l}\text { Parectropis similaria } \\
\text { (Hufnagel, 1767) }\end{array}$ & & & & & $x$ \\
\hline $\begin{array}{l}\text { Aethalura punctulata } \\
\text { ([Denis \& Schiffermüller], 1775) }\end{array}$ & 48 & $x$ & $x$ & $x$ & $x$ \\
\hline $\begin{array}{l}\text { Ematurga atomaria } \\
\text { (Linnaeus, 1758) }\end{array}$ & 1 & $x$ & & $x$ & \\
\hline $\begin{array}{l}\text { Bupalus piniaria } \\
\text { (Linnaeus, 1758) }\end{array}$ & 9 & $x$ & $x$ & & \\
\hline $\begin{array}{l}\text { Cabera pusaria } \\
\text { (Linnaeus, 1758) }\end{array}$ & 28 & $x$ & $x$ & $x$ & $x$ \\
\hline $\begin{array}{l}\text { Cabera exanthemata } \\
\text { (Scopoli, 1763) }\end{array}$ & 25 & $x$ & $x$ & $x$ & $x$ \\
\hline $\begin{array}{l}\text { Lomographa bimaculata } \\
\text { (Fabricius, 1775) }\end{array}$ & 6 & $x$ & $x$ & & $x$ \\
\hline $\begin{array}{l}\text { Lontographa temerata } \\
\text { ([Denis \& Schiffermüller], 1775) }\end{array}$ & 3 & $x$ & $x$ & $x$ & $x$ \\
\hline $\begin{array}{l}\text { Campaea margaritata } \\
\text { (Linnaeus, 1761) }\end{array}$ & 12 & $x$ & $x$ & $x$ & \\
\hline $\begin{array}{l}\text { Siona lineata } \\
\text { (Scopoli, 1763) }\end{array}$ & 26 & $x$ & $x$ & & \\
\hline $\begin{array}{l}\text { Chariaspilates formosaria } \\
\text { (Eversrnann, 1837) }\end{array}$ & & & & & $x$ \\
\hline \multicolumn{6}{|l|}{ Notodontidae Stephens, 1829} \\
\hline $\begin{array}{l}\text { Cerura erminea } \\
\text { (Esper, 1783) }\end{array}$ & 1 & & & & \\
\hline $\begin{array}{l}\text { Furcula bicuspis } \\
\text { (Borkhausen, 1790) }\end{array}$ & 8 & & & & \\
\hline $\begin{array}{l}\text { Furcula furcula } \\
\text { (Clerck, 1759) }\end{array}$ & 2 & $x$ & $x$ & & $x$ \\
\hline $\begin{array}{l}\text { Harpyia milhauseri } \\
\text { (Fabricius, 1775) }\end{array}$ & 1 & $x$ & $x$ & & \\
\hline $\begin{array}{l}\text { Stauropus fagi } \\
\text { (Linnaeus, 1758) }\end{array}$ & 23 & $x$ & $x$ & & \\
\hline $\begin{array}{l}\text { Drymonia velitaris } \\
\text { (Hufnagel, 1766) }\end{array}$ & 3 & $x$ & & & \\
\hline
\end{tabular}




\begin{tabular}{|c|c|c|c|c|c|}
\hline Taxonok & $\begin{array}{c}\text { Kanizsaberek } \\
\text { fénycsapda és } \\
\text { nappali mintavételek }\end{array}$ & $\begin{array}{l}\text { 1. mintavételi } \\
\text { hely }\end{array}$ & $\begin{array}{l}\text { 2. mintavételi } \\
\text { hely }\end{array}$ & $\begin{array}{l}\text { 3. mintavételi } \\
\text { hely }\end{array}$ & \begin{tabular}{|c|} 
Irodalmi adatok (Kovács \\
1953, Ábrahám 1989, \\
Uherkovich 1997) \\
\end{tabular} \\
\hline Drymonia obliterata Esper, 1785 & 1 & & & & \\
\hline $\begin{array}{l}\text { Drymonia dodonea } \\
\text { ([Denis \& Schiffermüller], 1775) }\end{array}$ & 29 & $x$ & $x$ & & $x$ \\
\hline $\begin{array}{l}\text { Drymonia ruficornis } \\
\text { (Hufnagel, 1766) }\end{array}$ & 11 & $\mathrm{x}$ & $\mathrm{x}$ & $x$ & \\
\hline $\begin{array}{l}\text { Gluphisia crenata } \\
\text { (Esper, 1785) }\end{array}$ & 6 & $x$ & $\mathrm{x}$ & & \\
\hline $\begin{array}{l}\text { Notodonta dromedarius } \\
\text { (Linnaeus, 1767) }\end{array}$ & 37 & $\mathrm{x}$ & $\mathrm{x}$ & $x$ & $\mathrm{x}$ \\
\hline $\begin{array}{l}\text { Notodonta tritophus } \\
\text { ([Denis \& Schiffermüller], 1775) }\end{array}$ & 1 & $x$ & & & \\
\hline $\begin{array}{l}\text { Notodonta ziczac } \\
\text { (Linnaeus, 1758) }\end{array}$ & 18 & $\mathrm{x}$ & $\mathrm{x}$ & & \\
\hline $\begin{array}{l}\text { Pheosia gnoma } \\
\text { (Fabricius, 1777) }\end{array}$ & 9 & $x$ & $\mathrm{x}$ & & \\
\hline $\begin{array}{l}\text { Pheosia tremula } \\
\text { (Clerck, 1759) }\end{array}$ & 12 & $\mathrm{x}$ & $\mathrm{x}$ & $\mathrm{x}$ & \\
\hline $\begin{array}{l}\text { Pterostoma palpina } \\
\text { (Clerck, 1759) }\end{array}$ & 12 & $\mathrm{x}$ & $\mathrm{x}$ & & $x$ \\
\hline $\begin{array}{l}\text { Spatalia argentina } \\
\text { ([Denis \& Schiffermüller, 1775) }\end{array}$ & 8 & $x$ & $\mathrm{x}$ & $x$ & \\
\hline $\begin{array}{l}\text { Ptilodon capucina } \\
\text { (Linnaeus, 1758) }\end{array}$ & 2 & $x$ & $\mathrm{x}$ & & \\
\hline $\begin{array}{l}\text { Ptilodon cucullina } \\
\text { ([Denis \& Schiffermüller], 1775) }\end{array}$ & 1 & $x$ & & & \\
\hline $\begin{array}{l}\text { Ptilophora plumigera } \\
\text { ([Denis \& Schiffermüller], 1775) }\end{array}$ & 2 & $\mathrm{x}$ & & & \\
\hline $\begin{array}{l}\text { Phalera bucephala } \\
\text { (Linnaeus, 1758) }\end{array}$ & 16 & $x$ & $\mathrm{x}$ & & \\
\hline $\begin{array}{l}\text { Clostera anastomosis } \\
\text { (Linnaeus, 1758) }\end{array}$ & 1 & $x$ & $x$ & & \\
\hline $\begin{array}{l}\text { Clostera curtula } \\
\text { (Linnaeus, 1758) }\end{array}$ & 3 & $x$ & $\mathrm{x}$ & & \\
\hline $\begin{array}{l}\text { Clostera pigra } \\
\text { (Hufnagel, 1766) }\end{array}$ & 3 & $\mathrm{x}$ & $\mathrm{x}$ & & $x$ \\
\hline $\begin{array}{l}\text { Thaumetopoea processionea } \\
\text { (Linnaeus, 1758) }\end{array}$ & 3 & & & & $x$ \\
\hline \multicolumn{6}{|l|}{ Erebidae Leach, 1815} \\
\hline $\begin{array}{l}\text { Rivula sericealis } \\
\text { (Scopoli, 1763) }\end{array}$ & 69 & $x$ & $\mathrm{x}$ & $x$ & $x$ \\
\hline $\begin{array}{l}\text { Parascotia fuliginaria } \\
\text { (Linnaeus, 1761) }\end{array}$ & 3 & & $\mathrm{x}$ & & \\
\hline $\begin{array}{l}\text { Schrankia taenialis } \\
\text { (Hübner, [1809]) }\end{array}$ & 2 & & & & \\
\hline $\begin{array}{l}\text { Laspeyria flexula } \\
\text { ([Denis \& Schiffermüller], 1775) }\end{array}$ & 5 & $\mathrm{x}$ & $\mathrm{x}$ & $x$ & \\
\hline $\begin{array}{l}\text { Trisateles emortualis } \\
\text { ([Denis \& Schiffermüller], 1775) }\end{array}$ & 1 & & & $x$ & $x$ \\
\hline $\begin{array}{l}\text { Paracolax tristalis } \\
\text { (Fabricius, 1794) }\end{array}$ & 10 & $\mathrm{x}$ & & $x$ & $x$ \\
\hline $\begin{array}{l}\text { Macrochilo cribrumalis } \\
\text { (Hübner, 1793) }\end{array}$ & & & & $x$ & \\
\hline $\begin{array}{l}\text { Herminia tarsipennalis } \\
\text { Treitschke, } 1835\end{array}$ & 2 & $x$ & $x$ & $x$ & $x$ \\
\hline $\begin{array}{l}\text { Herminia tarsicrinalis } \\
\text { (Knoch, 1782) }\end{array}$ & 46 & $x$ & $x$ & $x$ & \\
\hline $\begin{array}{l}\text { Herminia grisealis } \\
\text { ([Denis \& Schiffermüller], 1775) }\end{array}$ & 21 & $x$ & $x$ & $x$ & $x$ \\
\hline $\begin{array}{l}\text { Polypogon tentacularia } \\
\text { (Linnaeus, 1758) }\end{array}$ & 34 & $x$ & $x$ & & $x$ \\
\hline $\begin{array}{l}\text { Hypena proboscidalis } \\
\text { (Linnaeus, 1758) }\end{array}$ & 141 & $x$ & $x$ & $x$ & $x$ \\
\hline
\end{tabular}


TERMÉSZETVÉDELMI TERÜLETEN

\begin{tabular}{|c|c|c|c|c|c|}
\hline Taxonok & $\begin{array}{c}\text { Kanizsaberek } \\
\text { fénycsapda és } \\
\text { nappali mintavételek }\end{array}$ & $\begin{array}{l}\text { 1. mintavételi } \\
\text { hely }\end{array}$ & $\begin{array}{l}\text { 2. mintavételi } \\
\text { hely }\end{array}$ & $\begin{array}{l}\text { 3. mintavételi } \\
\text { hely }\end{array}$ & $\begin{array}{c}\text { Irodalmi adatok (Kovács } \\
\text { 1953, Ábrahám 1989, } \\
\text { Uherkovich 1997) }\end{array}$ \\
\hline $\begin{array}{l}\text { Hypena rostralis } \\
\text { (Linnaeus, 1758) }\end{array}$ & 4 & $x$ & $x$ & $x$ & \\
\hline $\begin{array}{l}\text { Colobochyla salicalis } \\
\text { ([Denis \& Schiffermüller], 1775) }\end{array}$ & 8 & $x$ & $x$ & $x$ & \\
\hline $\begin{array}{l}\text { Scoliopteryx libatrix } \\
\text { (Linnaeus, 1758) }\end{array}$ & 1 & $x$ & & & \\
\hline $\begin{array}{l}\text { Lymantria (Porthetria) dispar } \\
\text { (Linnaeus, 1758) }\end{array}$ & 2 & & & $\mathrm{x}$ & \\
\hline $\begin{array}{l}\text { Lymantria (Lymantria) monacha } \\
\text { (Linnaeus, 1758) }\end{array}$ & 1 & & & $x$ & $x$ \\
\hline $\begin{array}{l}\text { Euproctis chrysorrhoea } \\
\text { (Linnaeus, 1758) }\end{array}$ & 44 & $x$ & $x$ & $x$ & \\
\hline $\begin{array}{l}\text { Sphrageidus similis } \\
\text { (Fuessly, 1775) }\end{array}$ & & & $x$ & & $\mathrm{x}$ \\
\hline $\begin{array}{l}\text { Orgyia antiqua } \\
\text { (Linnaeus, 1758) }\end{array}$ & 1 & & & & \\
\hline $\begin{array}{l}\text { Laelia coenosa } \\
\text { (Hübner, 1808) }\end{array}$ & & & & $x$ & \\
\hline $\begin{array}{l}\text { Calliteara pudibunda } \\
\text { (Linnaeus, 1758) }\end{array}$ & 49 & $x$ & $x$ & & $x$ \\
\hline $\begin{array}{l}\text { Arctornis I-nigrum } \\
\text { (Müller, 1764) }\end{array}$ & 1 & & & & \\
\hline $\begin{array}{l}\text { Leucoma salicis } \\
\text { (Linnaeus, 1758) }\end{array}$ & 3 & & & & \\
\hline $\begin{array}{l}\text { Spilarctia lutea } \\
\text { (Hufnagel, 1766) }\end{array}$ & 257 & $x$ & $\mathrm{x}$ & $\mathrm{x}$ & $\mathrm{x}$ \\
\hline $\begin{array}{l}\text { Spilosoma lubricipedum } \\
\text { (Linnaeus, 1758) }\end{array}$ & 216 & $x$ & $x$ & $x$ & $x$ \\
\hline $\begin{array}{l}\text { Spilosoma urticae } \\
\text { (Esper, 1789) }\end{array}$ & 30 & $x$ & $x$ & $\mathrm{x}$ & \\
\hline Diaphora mendica (Clerck, 1759) & 11 & $x$ & $x$ & & \\
\hline $\begin{array}{l}\text { Phragmatobia fuliginosa } \\
\text { (Linnaeus, 1758) }\end{array}$ & 123 & $x$ & $x$ & $x$ & $\mathrm{x}$ \\
\hline $\begin{array}{l}\text { Arctia caja } \\
\text { (Linnaeus, 1758) }\end{array}$ & 8 & $x$ & $x$ & $x$ & \\
\hline $\begin{array}{l}\text { Arctia villica } \\
\text { (Linnaeus, 1758) }\end{array}$ & 48 & $x$ & $x$ & $x$ & \\
\hline $\begin{array}{l}\text { Rhyparia purpurata } \\
\text { (Linnaeus, 1758) }\end{array}$ & 5 & $x$ & & & \\
\hline $\begin{array}{l}\text { Diacrisia sannio } \\
\text { (Linnaeus, 1758) }\end{array}$ & 114 & $x$ & $x$ & & \\
\hline $\begin{array}{l}\text { Callimorpha dominula } \\
\text { (Linnaeus, 1758) }\end{array}$ & 40 & & & $x$ & $x$ \\
\hline $\begin{array}{l}\text { Euplagia quadripunctaria } \\
\text { (Poda, 1761) }\end{array}$ & & $x$ & & $x$ & \\
\hline $\begin{array}{l}\text { Tyria jacobaeae } \\
\text { (Linnaeus, 1758) }\end{array}$ & 3 & & & & \\
\hline $\begin{array}{l}\text { Miltochrista miniata } \\
\text { (J. R. Forster, 1771) }\end{array}$ & 76 & $x$ & & $x$ & $\mathrm{x}$ \\
\hline $\begin{array}{l}\text { Cybosia mesomella } \\
\text { (Linnaeus, 1758) }\end{array}$ & 18 & $x$ & & & \\
\hline $\begin{array}{l}\text { Thumata senex } \\
\text { (Hübner, [1808]) }\end{array}$ & 46 & $x$ & $\mathrm{x}$ & $\mathrm{x}$ & $\mathrm{x}$ \\
\hline $\begin{array}{l}\text { Pelosia muscerda } \\
\text { (Hufnagel, 1766) }\end{array}$ & 862 & $x$ & $x$ & $x$ & $x$ \\
\hline $\begin{array}{l}\text { Pelosia obtusa } \\
\text { (Herrich-Schaffer, [1847]) }\end{array}$ & 8 & $x$ & $x$ & & \\
\hline $\begin{array}{l}\text { Lithosia quadra } \\
\text { (Linnaeus, 1758) }\end{array}$ & 573 & $x$ & $x$ & $x$ & \\
\hline $\begin{array}{l}\text { Eilema griseola } \\
\text { (Hübner, [1803]) }\end{array}$ & 2 & & & $x$ & $x$ \\
\hline $\begin{array}{l}\text { Eilema depressa } \\
\text { (Esper, [1787]) }\end{array}$ & 27 & $\mathrm{x}$ & & $\mathrm{x}$ & \\
\hline
\end{tabular}




\begin{tabular}{|c|c|c|c|c|c|}
\hline Taxonok & $\begin{array}{c}\text { Kanizsaberek } \\
\text { fénycsapda és } \\
\text { nappali mintavételek }\end{array}$ & $\begin{array}{l}\text { 1. mintavételi } \\
\text { hely }\end{array}$ & $\begin{array}{l}\text { 2. mintavételi } \\
\text { hely }\end{array}$ & $\begin{array}{l}\text { 3. mintavételi } \\
\text { hely }\end{array}$ & $\begin{array}{c}\text { Irodalmi adatok (Kovács } \\
\text { 1953, Ábrahám 1989, } \\
\text { Uherkovich 1997) } \\
\end{array}$ \\
\hline $\begin{array}{l}\text { Eilema lutarella } \\
\text { (Linnaeus, 1758) }\end{array}$ & 39 & $x$ & $\mathrm{x}$ & & $x$ \\
\hline $\begin{array}{l}\text { Eilema lurideola } \\
\text { ([Zincken], 1817) }\end{array}$ & 6 & $x$ & $x$ & & \\
\hline $\begin{array}{l}\text { Eilema complana } \\
\text { (Linnaeus, 1758) }\end{array}$ & 5 & & $x$ & & \\
\hline $\begin{array}{l}\text { Eilema pygmaeola pallifrons } \\
\text { (Zeller, 1847) }\end{array}$ & & & & $x$ & \\
\hline $\begin{array}{l}\text { Eilema sororcula } \\
\text { (Hufnagel, 1766) }\end{array}$ & 255 & $x$ & $x$ & $x$ & $x$ \\
\hline $\begin{array}{l}\text { Setina roscida } \\
\text { ([Denis \& Schiffermüller], 1775) }\end{array}$ & & & & & $\mathrm{x}$ \\
\hline $\begin{array}{l}\text { Amata phegea } \\
\text { (Linnaeus, 1758) }\end{array}$ & & & & & $\mathrm{x}$ \\
\hline $\begin{array}{l}\text { Dysauxes ancilla } \\
\text { (Linnaeus, 1767) }\end{array}$ & & & & $\mathrm{x}$ & \\
\hline $\begin{array}{l}\text { Catephia alchymista } \\
\text { ([Denis \& Schiffermüller], 1775) }\end{array}$ & 2 & $x$ & & & \\
\hline $\begin{array}{l}\text { Euclidia (Callistege) mi } \\
\text { (Clerck, 1759) }\end{array}$ & & & & & $x$ \\
\hline $\begin{array}{l}\text { Minucia lunaris } \\
\text { ([Denis \& Schiffermüller], 1775) }\end{array}$ & 2 & $x$ & $\mathrm{x}$ & & \\
\hline $\begin{array}{l}\text { Catocala fulminea } \\
\text { (Scopoli, 1763) }\end{array}$ & 1 & $x$ & & & \\
\hline $\begin{array}{l}\text { Catocala fraxini } \\
\text { (Linnaeus, 1758) }\end{array}$ & & & $\mathrm{x}$ & & \\
\hline \multicolumn{6}{|l|}{ Nolidae Bruand, 1846} \\
\hline $\begin{array}{l}\text { Meganola albula ( } \\
\text { [Denis \& Schiffermüller], 1775) }\end{array}$ & 13 & $x$ & $\mathrm{x}$ & $x$ & $x$ \\
\hline $\begin{array}{l}\text { Nola aerugula } \\
\text { (Hübner, 1793) }\end{array}$ & 7 & $x$ & & $x$ & \\
\hline $\begin{array}{l}\text { Nola cicatricalis } \\
\text { (Treitschke, 1835) }\end{array}$ & & & & $x$ & \\
\hline $\begin{array}{l}\text { Pseudoips prasinana (Linnaeus, } \\
\text { 1758) (fagana Fabricius, 1781) }\end{array}$ & 92 & $\mathrm{x}$ & $\mathrm{x}$ & $\mathrm{x}$ & \\
\hline $\begin{array}{l}\text { Earias clorana } \\
\text { (Linnaeus, 1761) }\end{array}$ & 2 & $x$ & $x$ & $\mathrm{x}$ & \\
\hline $\begin{array}{l}\text { Nycteola asiatica } \\
\text { (Krulikovsky, 1904) }\end{array}$ & 1 & & & & \\
\hline \multicolumn{6}{|l|}{ Noctuidae Latreille, 1809} \\
\hline $\begin{array}{l}\text { Abrostola tripartita } \\
\text { (Hufnagel, 1766) }\end{array}$ & 4 & & & & \\
\hline $\begin{array}{l}\text { Abrostola asclepiadis } \\
\text { ([Denis \& Schiffermüller], 1775) }\end{array}$ & 1 & & $x$ & & $x$ \\
\hline $\begin{array}{l}\text { Abrostola triplasia } \\
\text { (Linnaeus, 1758) }\end{array}$ & 9 & $x$ & $x$ & $x$ & $\mathrm{x}$ \\
\hline $\begin{array}{l}\text { Macdunnoughia confusa } \\
\text { (Stephens, 1850) }\end{array}$ & 3 & $\mathrm{x}$ & & & \\
\hline $\begin{array}{l}\text { Diachrysia chrysitis } \\
\text { (Linnaeus, 1758) }\end{array}$ & 83 & $x$ & $\mathrm{x}$ & $\mathrm{x}$ & \\
\hline $\begin{array}{l}\text { Autographa gamma } \\
\text { (Linnaeus, 1758) }\end{array}$ & 6 & $x$ & $x$ & $\mathrm{x}$ & \\
\hline $\begin{array}{l}\text { Plusia festucae } \\
\text { (Linnaeus, 1758) }\end{array}$ & 2 & & $\mathrm{x}$ & & \\
\hline $\begin{array}{l}\text { Protodeltote pygarga } \\
\text { (Hufnagel, 1766) }\end{array}$ & 30 & $x$ & $\mathrm{x}$ & $x$ & $x$ \\
\hline $\begin{array}{l}\text { Deltote uncula } \\
\text { (Clerck, 1759) }\end{array}$ & 15 & $x$ & $x$ & $x$ & \\
\hline $\begin{array}{l}\text { Deltote bankiana } \\
\text { (Fabricius, 1775) }\end{array}$ & 4 & $x$ & & $x$ & $x$ \\
\hline $\begin{array}{l}\text { Colocasia coryli } \\
\text { (Linnaeus, 1758) }\end{array}$ & 137 & $x$ & $x$ & $x$ & $x$ \\
\hline
\end{tabular}


TERMÉSZETVÉDELMI TERÜLETEN

\begin{tabular}{|c|c|c|c|c|c|}
\hline Taxonok & $\begin{array}{c}\text { Kanizsaberek } \\
\text { fénycsapda és } \\
\text { nappali mintavételek }\end{array}$ & $\begin{array}{l}\text { 1. mintavételi } \\
\text { hely }\end{array}$ & $\begin{array}{l}\text { 2. mintavételi } \\
\text { hely }\end{array}$ & $\begin{array}{l}\text { 3. mintavételi } \\
\text { hely }\end{array}$ & $\begin{array}{c}\text { Irodalmi adatok (Kovács } \\
\text { 1953, Ábrahám 1989, } \\
\text { Uherkovich 1997) } \\
\end{array}$ \\
\hline $\begin{array}{l}\text { Diloba caeruleocephala } \\
\text { (Linnaeus, 1758) }\end{array}$ & 2 & $x$ & & & \\
\hline $\begin{array}{l}\text { Craniophora ligustri } \\
\text { ([Denis \& Schiffermüller], 1775) }\end{array}$ & 13 & $\mathrm{x}$ & $x$ & & $x$ \\
\hline $\begin{array}{l}\text { Moma alpium } \\
\text { (Osbeck 1778) }\end{array}$ & 2 & & & $x$ & \\
\hline $\begin{array}{l}\text { Simyra albovenosa } \\
\text { (Goeze, 1781) }\end{array}$ & 4 & & $x$ & & $\mathrm{x}$ \\
\hline $\begin{array}{l}\text { Acronicta (Jocheaera) alni } \\
\text { (Linnaeus, 1767) }\end{array}$ & 7 & $x$ & $x$ & $\mathrm{x}$ & \\
\hline $\begin{array}{l}\text { Acronicta (Triaena) cuspis } \\
\text { (Hübner, 1813) }\end{array}$ & 41 & $x$ & $x$ & $\mathrm{x}$ & \\
\hline $\begin{array}{l}\text { Acronicta (Triaena) tridens } \\
\text { ([Denis \& Schiffermüller], 1775) }\end{array}$ & 4 & $x$ & $x$ & & \\
\hline $\begin{array}{l}\text { Acronicta (Triaena) psi } \\
\text { (Linnaeus, 1758) }\end{array}$ & 1 & $x$ & & & \\
\hline $\begin{array}{l}\text { Acronicta (Hyboma) strigosa } \\
\text { ([Denis \& Schiffermüller], 1775) }\end{array}$ & 6 & $\mathrm{x}$ & $\mathrm{x}$ & $\mathrm{x}$ & $\mathrm{x}$ \\
\hline $\begin{array}{l}\text { Acronicta (Viminia) auricoma } \\
\text { ([Denis \& Schiffermüller], 1775) }\end{array}$ & 1 & $x$ & & & \\
\hline $\begin{array}{l}\text { Acronicta (Viminia) } \\
\text { rumicis (Linnaeus, 1758) }\end{array}$ & 13 & $x$ & $x$ & $x$ & \\
\hline $\begin{array}{l}\text { Acronicta (Acronicta) } \\
\text { leporina (Linnaeus, 1758) }\end{array}$ & 10 & $x$ & $x$ & $x$ & \\
\hline $\begin{array}{l}\text { Acrouicta (Subacronicta) } \\
\text { megacephala } \\
\text { ([Denis \& Schiffermüller], 1775) }\end{array}$ & 3 & $x$ & $x$ & & \\
\hline $\begin{array}{l}\text { Tyta luctuosa } \\
\text { ([Denis \& Schiffermüller], 1775) }\end{array}$ & & & & & $x$ \\
\hline $\begin{array}{l}\text { Shargacucullia } \\
\text { (Shargacucullia) verbasci } \\
\text { (Linnaeus, 1758) }\end{array}$ & 5 & $x$ & $x$ & & \\
\hline $\begin{array}{l}\text { Cucullia absinthii } \\
\text { (Linnaeus, 1761) }\end{array}$ & 8 & & & & \\
\hline $\begin{array}{l}\text { Cucullia umbratica } \\
\text { (Linnaeus, 1758) }\end{array}$ & 1 & $x$ & & $x$ & \\
\hline $\begin{array}{l}\text { Omphalophana antirrhinii } \\
\text { (Hübner, 1803) }\end{array}$ & 4 & & & & $x$ \\
\hline $\begin{array}{l}\text { Amphipyra (Amphipyra) livida } \\
\text { ([Denis \& Schiffermüller], 1775) }\end{array}$ & 2 & $x$ & & & \\
\hline $\begin{array}{l}\text { Asteroscopus sphinx } \\
\text { (Hufnagel, 1766) }\end{array}$ & 7 & $x$ & & & \\
\hline $\begin{array}{l}\text { Allophyes oxyacanthae } \\
\text { (Linnaeus, 1758) }\end{array}$ & 18 & $x$ & & & \\
\hline $\begin{array}{l}\text { Eucarta amethystina } \\
\text { (Hübner, 1803) }\end{array}$ & 8 & & $x$ & $\mathrm{x}$ & \\
\hline $\begin{array}{l}\text { Eucarta virgo } \\
\text { (Treitschke, 1835) }\end{array}$ & 4 & $\mathrm{x}$ & $x$ & & \\
\hline $\begin{array}{l}\text { Pyrrhia umbra } \\
\text { (Hufnagel, 1766) }\end{array}$ & 2 & & $x$ & & \\
\hline Heliothis adaucta Butler, 1878 & 1 & & & & $x$ \\
\hline $\begin{array}{l}\text { Cryphia (Euthales) algae } \\
\text { (Fabricius, 1775) }\end{array}$ & 1 & & & $\mathrm{x}$ & \\
\hline Callopistria juventina (Stoll, 1782) & 3 & & & $x$ & \\
\hline $\begin{array}{l}\text { Pseudeustrotia candidula } \\
\text { ([Denis \& Schiffermüller], 1775) }\end{array}$ & 14 & $x$ & $x$ & & $x$ \\
\hline $\begin{array}{l}\text { Spodoptera exigua } \\
\text { (Hübner, 1808) }\end{array}$ & 1 & & & & $x$ \\
\hline $\begin{array}{l}\text { Elaphria venustula } \\
\text { (Hübner, 1790) }\end{array}$ & 35 & $x$ & $x$ & $x$ & $x$ \\
\hline $\begin{array}{l}\text { Caradrina (Caradrina) morpheus } \\
\text { (Hufnagel, 1766) }\end{array}$ & 31 & $\mathrm{x}$ & $x$ & & \\
\hline
\end{tabular}




\begin{tabular}{|c|c|c|c|c|c|}
\hline Taxonok & $\begin{array}{c}\text { Kanizsaberek } \\
\text { fénycsapda és } \\
\text { nappali mintavételek }\end{array}$ & $\begin{array}{l}\text { 1. mintavételi } \\
\text { hely }\end{array}$ & $\begin{array}{l}\text { 2. mintavételi } \\
\text { hely }\end{array}$ & $\begin{array}{l}\text { 3. mintavételi } \\
\text { hely }\end{array}$ & $\begin{array}{c}\text { Irodalmi adatok (Kovács } \\
\text { 1953, Ábrahám 1989, } \\
\text { Uherkovich 1997) }\end{array}$ \\
\hline $\begin{array}{l}\text { Caradrina (Paradrina) clavipalpis } \\
\text { (Scopoli, 1763) }\end{array}$ & 1 & & & & \\
\hline $\begin{array}{l}\text { Hoplodrina octogenaria } \\
\text { (Goeze, 1781) } \\
\text { (=alsines Brahm, 1791) }\end{array}$ & 53 & $x$ & & & \\
\hline $\begin{array}{l}\text { Hoplodrina ambigua } \\
\text { ([Denis \& Schiffermüller], 1775) }\end{array}$ & 45 & $x$ & $x$ & & \\
\hline $\begin{array}{l}\text { Charanyca trigrammica } \\
\text { (Hufnagel, 1766) }\end{array}$ & 23 & $x$ & $x$ & $\mathrm{x}$ & $x$ \\
\hline $\begin{array}{l}\text { Rusina ferruginea } \\
\text { (Esper, 1785) }\end{array}$ & 7 & $x$ & $x$ & & \\
\hline $\begin{array}{l}\text { Dypterygia scabriuscula } \\
\text { (Linnaeus, 1758) }\end{array}$ & 8 & $x$ & $\mathrm{x}$ & $x$ & $x$ \\
\hline $\begin{array}{l}\text { Trachea atriplicis } \\
\text { (Linnaeus, 1758) }\end{array}$ & 4 & & $x$ & $\mathrm{x}$ & \\
\hline $\begin{array}{l}\text { Thalpophila matura } \\
\text { (Hufnagel, 1766) }\end{array}$ & 3 & & $x$ & & \\
\hline $\begin{array}{l}\text { Actinotia polyodon } \\
\text { (Clerck, 1759) }\end{array}$ & 19 & $\mathrm{x}$ & $x$ & & \\
\hline $\begin{array}{l}\text { Actinotia radiosa } \\
\text { (Esper, 1804) }\end{array}$ & & & & $\mathrm{x}$ & \\
\hline $\begin{array}{l}\text { Phlogophora meticulosa } \\
\text { (Linnaeus, 1758) }\end{array}$ & 8 & & $x$ & & \\
\hline $\begin{array}{l}\text { Calamia tridens } \\
\text { (Hufnagel, 1766) }\end{array}$ & & & & & $\mathrm{x}$ \\
\hline $\begin{array}{l}\text { Euplexia lucipara } \\
\text { (Linnaeus, 1758) }\end{array}$ & 22 & $x$ & $x$ & $\mathrm{x}$ & $\mathrm{x}$ \\
\hline $\begin{array}{l}\text { Gortyna flavago } \\
\text { ([Denis \& Schiffermüller], 1775) }\end{array}$ & 2 & & & & \\
\hline $\begin{array}{l}\text { Hydraecia micacea } \\
\text { (Esper, 1789) }\end{array}$ & 1 & & $x$ & & \\
\hline $\begin{array}{l}\text { Rhizedra lutosa } \\
\text { (Hübner, 1803) }\end{array}$ & 3 & $\mathrm{x}$ & & & \\
\hline $\begin{array}{l}\text { Sedina buettneri } \\
\text { (E. Hering, 1858) }\end{array}$ & 4 & $x$ & & & \\
\hline $\begin{array}{l}\text { Nonagria typhae } \\
\text { (Thunberg, 1784) }\end{array}$ & 1 & & & & \\
\hline $\begin{array}{l}\text { Phragniatiphila nexa } \\
\text { (Hübner, 1808) }\end{array}$ & 1 & & $x$ & $\mathrm{x}$ & \\
\hline $\begin{array}{l}\text { Denticucullus pygmina } \\
\text { (Haworth, 1809) }\end{array}$ & 12 & $\mathrm{x}$ & $x$ & & \\
\hline $\begin{array}{l}\text { Photedes minima } \\
\text { (Haworth, 1809) }\end{array}$ & 1 & $x$ & & & \\
\hline $\begin{array}{l}\text { Photedes extrema } \\
\text { (Hübner, 1809) }\end{array}$ & 25 & $x$ & $x$ & $\mathrm{x}$ & \\
\hline $\begin{array}{l}\text { Pabulatrix pabulatricula } \\
\text { (Brahm, 1791) }\end{array}$ & & & & & $x$ \\
\hline $\begin{array}{l}\text { Apamea monoglypha } \\
\text { (Hufnagel, 1766) }\end{array}$ & 7 & $x$ & & & $x$ \\
\hline $\begin{array}{l}\text { Apamea syriaca tallosi } \\
\text { Kovacs \& Varga, } 1969\end{array}$ & & & & $\mathrm{x}$ & \\
\hline $\begin{array}{l}\text { Apamea sublustris } \\
\text { (Esper, 1788) }\end{array}$ & 4 & $x$ & & & \\
\hline $\begin{array}{l}\text { Apamea remissa } \\
\text { (Hübner, 1809) }\end{array}$ & 8 & $\mathrm{x}$ & & & $x$ \\
\hline $\begin{array}{l}\text { Apamea crenata } \\
\text { (Hufnagel, 1766) }\end{array}$ & 1 & $\mathrm{x}$ & & & \\
\hline $\begin{array}{l}\text { Apamea anceps } \\
\text { ([Denis \& Schiffermüller], 1775) }\end{array}$ & 1 & & & $\mathrm{x}$ & \\
\hline $\begin{array}{l}\text { Apamea sordens } \\
\text { (Hufnagel, 1766) }\end{array}$ & 1 & $\mathrm{x}$ & & & $\mathrm{x}$ \\
\hline $\begin{array}{l}\text { Apamea unanimis } \\
\text { (Hübner, 1813) }\end{array}$ & 2 & $\mathrm{x}$ & & & \\
\hline
\end{tabular}




\begin{tabular}{|c|c|c|c|c|c|}
\hline Taxonok & $\begin{array}{c}\text { Kanizsaberek } \\
\text { fénycsapda és } \\
\text { nappali mintavételek }\end{array}$ & $\begin{array}{l}\text { 1. mintavételi } \\
\text { hely }\end{array}$ & $\begin{array}{l}\text { 2. mintavételi } \\
\text { hely }\end{array}$ & $\begin{array}{l}\text { 3. mintavételi } \\
\text { hely }\end{array}$ & $\begin{array}{c}\text { Irodalmi adatok (Kovács } \\
\text { 1953, Ábrahám 1989, } \\
\text { Uherkovich 1997) }\end{array}$ \\
\hline $\begin{array}{l}\text { Loscopia scolopacina } \\
\text { (Esper, 1788) }\end{array}$ & 5 & $x$ & & & \\
\hline $\begin{array}{l}\text { Mesapamea secalis } \\
\text { (Linnaeus, 1758) }\end{array}$ & 1 & $x$ & & & $x$ \\
\hline $\begin{array}{l}\text { Mesoligia furuncula } \\
\text { ([Denis \& Schiffermüller], 1775) }\end{array}$ & 2 & & $x$ & & \\
\hline $\begin{array}{l}\text { Oligia strigilis } \\
\text { (Linnaeus, 1758) }\end{array}$ & 52 & $x$ & & $x$ & \\
\hline $\begin{array}{l}\text { Oligia latruncula } \\
\text { ([Denis \& Schiffermüller], 1775) }\end{array}$ & 34 & $x$ & $x$ & $x$ & \\
\hline $\begin{array}{l}\text { Oligia versicolor } \\
\text { (Borkhausen, 1792) }\end{array}$ & 6 & & & & $x$ \\
\hline $\begin{array}{l}\text { Cosmia (Nemus) pyralina } \\
\text { ([Denis \& Schiffermüller], 1775) }\end{array}$ & 1 & & & & \\
\hline $\begin{array}{l}\text { Atethmia centrago } \\
\text { (Haworth, 1809) }\end{array}$ & 2 & & & & \\
\hline $\begin{array}{l}\text { Tiliacea aurago } \\
\text { ([Denis \& Schiffermüller], 1775) }\end{array}$ & 3 & & & & \\
\hline $\begin{array}{l}\text { Lithophane ornitopus } \\
\text { (Hufnagel, 1766) }\end{array}$ & & & & & $x$ \\
\hline $\begin{array}{l}\text { Lithophane furcifera } \\
\text { (Hufnagel, 1766) }\end{array}$ & & & & & $x$ \\
\hline $\begin{array}{l}\text { Xylena exsoleta } \\
\text { (Linnaeus, 1758) }\end{array}$ & & & & & $x$ \\
\hline $\begin{array}{l}\text { Xylena vetusta } \\
\text { (Hübner, 1813) }\end{array}$ & & & & & $x$ \\
\hline $\begin{array}{l}\text { Eupsilia transversa } \\
\text { (Hufnagel, 1766) }\end{array}$ & 9 & $x$ & & & \\
\hline $\begin{array}{l}\text { Conistra (Conistra) } \\
\text { vaccinii (Linnaeus, 1761) }\end{array}$ & 82 & $x$ & $x$ & $x$ & \\
\hline $\begin{array}{l}\text { Conistra (Conistra) } \\
\text { rubiginosa (Seopoli, 1763) }\end{array}$ & 1 & $x$ & & & \\
\hline $\begin{array}{l}\text { Conistra (Dasycampa) } \\
\text { erythrocephala } \\
\text { ([Denis \& Schiffermüller], 1775) }\end{array}$ & 5 & $x$ & $x$ & & \\
\hline $\begin{array}{l}\text { Agrochola (Anchoscelis) litura } \\
\text { (Linnaeus, 1761) }\end{array}$ & 23 & $x$ & & & \\
\hline $\begin{array}{l}\text { Agrochola (Anchoscelis) helvola } \\
\text { (Linnaeus, 1758) }\end{array}$ & 15 & $x$ & & & \\
\hline $\begin{array}{l}\text { Agrochola (Leplologia) lota } \\
\text { (Clerck, 1759) }\end{array}$ & 21 & $x$ & & & \\
\hline $\begin{array}{l}\text { Agrochola (Leplologia) macilenta } \\
\text { (Hübner, 1809) }\end{array}$ & 1 & & & & \\
\hline $\begin{array}{l}\text { Agrochola (Sunira) circellaris } \\
\text { (Hufnage I, 1766) }\end{array}$ & 11 & $x$ & & & \\
\hline $\begin{array}{l}\text { Agrochola (Propenistra) laevis } \\
\text { (Hübner, 1803) }\end{array}$ & 4 & $x$ & & & \\
\hline $\begin{array}{l}\text { Xauthia togata } \\
\text { (Esper, 1788) }\end{array}$ & 5 & & & & \\
\hline $\begin{array}{l}\text { Cirrhia icteritia } \\
\text { (Hufnagel, 1766) }\end{array}$ & 1 & & & & \\
\hline $\begin{array}{l}\text { Atypha pulmonaris } \\
\text { (Esper, 1790) }\end{array}$ & 2 & & & $x$ & $x$ \\
\hline $\begin{array}{l}\text { Brachylomia viminalis } \\
\text { (Fabricius, 1777) }\end{array}$ & 3 & & & & \\
\hline $\begin{array}{l}\text { Griposia aprilina } \\
\text { (Linnaeus, 1758) }\end{array}$ & 1 & & $x$ & & \\
\hline $\begin{array}{l}\text { Ammoconia caecimacula } \\
\text { ([Denis \& Schiffermüller], 1775) }\end{array}$ & 1 & & & & \\
\hline $\begin{array}{l}\text { Aporophyla (Phylapora) lutulenta } \\
\text { ([Denis \& Schiffermüller], 1775) }\end{array}$ & 5 & $x$ & & & \\
\hline $\begin{array}{l}\text { Mythimna (Mythimna) turca } \\
\text { (Linnaeus, 1761) }\end{array}$ & 660 & $x$ & $x$ & $x$ & $x$ \\
\hline $\begin{array}{l}\text { Mythimna (Mythimna) pudorina } \\
\text { ([Denis \& Schiffermüller], 1775) }\end{array}$ & 31 & $x$ & & & $x$ \\
\hline
\end{tabular}




\begin{tabular}{|c|c|c|c|c|c|}
\hline Taxonok & $\begin{array}{c}\text { Kanizsaberek } f \\
\text { énycsapda és } \\
\text { nappali mintavételek }\end{array}$ & $\begin{array}{l}\text { 1. mintavételi } \\
\text { hely }\end{array}$ & $\begin{array}{l}\text { 2. mintavételi } \\
\text { hely }\end{array}$ & $\begin{array}{l}\text { 3. mintavételi } \\
\text { hely }\end{array}$ & $\begin{array}{c}\text { Irodalmi adatok (Kovács } \\
\text { 1953, Ábrahám 1989, } \\
\text { Uherkovich 1997) }\end{array}$ \\
\hline $\begin{array}{l}\text { Mythimna (Mythimna) conigera } \\
\text { ([Denis \& Schiffermüller], 1775) }\end{array}$ & 1 & & & $x$ & \\
\hline $\begin{array}{l}\text { Mythimna (Mythimna) pallens } \\
\text { (Linnaeus, 1758) }\end{array}$ & 18 & $x$ & $x$ & & $x$ \\
\hline $\begin{array}{l}\text { Mythimna (Mythimna) impura } \\
\text { (Hübner, 1808) }\end{array}$ & 7 & $x$ & & & $x$ \\
\hline $\begin{array}{l}\text { Mythimna (Hyphilare) albipuncta } \\
\text { ([Denis \& Schiffermüller], 1775) }\end{array}$ & 10 & $x$ & $x$ & $x$ & \\
\hline $\begin{array}{l}\text { Mythinma (Hyphilare) ferrago } \\
\text { (Fabricius, 1787) }\end{array}$ & 7 & $x$ & & & \\
\hline $\begin{array}{l}\text { Mythimna (Hyphilare) l-album } \\
\text { (Linnaeus, 1767) }\end{array}$ & 2 & $x$ & & $x$ & \\
\hline $\begin{array}{l}\text { Senta flammea } \\
\text { (Curtis, 1828) }\end{array}$ & 1 & & $x$ & & \\
\hline $\begin{array}{l}\text { Hadula (Calocestra) trifolii } \\
\text { (Hufnagel, 1766) }\end{array}$ & 8 & $x$ & $x$ & & \\
\hline $\begin{array}{l}\text { Sideridis (Aneda) rivularis } \\
\text { (Fabricius, 1775) }\end{array}$ & 7 & $x$ & & & \\
\hline $\begin{array}{l}\text { Heliophobus reticulata } \\
\text { (Goeze, 1781) }\end{array}$ & & & & & $x$ \\
\hline $\begin{array}{l}\text { Conisania (Luteohadena) luteago } \\
\text { ([Denis \& Schiffermüller], 1775) }\end{array}$ & & & & & $\mathrm{x}$ \\
\hline $\begin{array}{l}\text { Polia nebulosa } \\
\text { (Hufnagel, 1766) }\end{array}$ & 4 & $x$ & & & $x$ \\
\hline $\begin{array}{l}\text { Mamestra brassicae } \\
\text { (Linnaeus, 1758) }\end{array}$ & 3 & & $x$ & & \\
\hline $\begin{array}{l}\text { Melanchra persicariae } \\
\text { (Linnaeus, 1761) }\end{array}$ & 5 & $x$ & & & \\
\hline $\begin{array}{l}\text { Ceramica pisi } \\
\text { (Linnaeus, 1758) }\end{array}$ & 17 & $x$ & $x$ & & \\
\hline $\begin{array}{l}\text { Lacanobia (Laeanobia) w-latinum } \\
\text { (Hufnagel, 1766) }\end{array}$ & 5 & $x$ & & & \\
\hline $\begin{array}{l}\text { Lacanobia (Dianobia) thalassina } \\
\text { (Hufnagel, 1766) }\end{array}$ & 54 & $x$ & $x$ & & \\
\hline $\begin{array}{l}\text { Lacanobia (Dianobia) contigua } \\
\text { ([Denis \& Schiffermüller], 1775) }\end{array}$ & 18 & $x$ & $x$ & & \\
\hline $\begin{array}{l}\text { Lacanobia (Dianobia) suasa } \\
\text { ([Denis \& Schiffermüller], 1775) }\end{array}$ & 4 & $x$ & & $x$ & \\
\hline $\begin{array}{l}\text { Lacanobia (Diataraxia) oleracea } \\
\text { (Linnaeus, 1758) }\end{array}$ & 33 & $x$ & $x$ & & \\
\hline $\begin{array}{l}\text { Lacanobia (Diataraxia) splendens } \\
\text { (Hübner, 1808) }\end{array}$ & & $x$ & & & \\
\hline $\begin{array}{l}\text { Hada plebeja } \\
\text { (Linnaeus, 1761) }\end{array}$ & 2 & $x$ & $x$ & & \\
\hline $\begin{array}{l}\text { Hecatera bicolorata } \\
\text { (Hufnagel, 1766) }\end{array}$ & 2 & & $x$ & & \\
\hline $\begin{array}{l}\text { Panolis flammea } \\
\text { ([Denis \& Schiffermüller], 1775) }\end{array}$ & 22 & $x$ & $x$ & & \\
\hline $\begin{array}{l}\text { Orthosia (Orthosia) incerta } \\
\text { (Hufnagel, 1766) }\end{array}$ & 41 & $x$ & $x$ & $x$ & \\
\hline $\begin{array}{l}\text { Orthosia (Monima) cerasi } \\
\text { (Fabricius, 1775) }\end{array}$ & 15 & $x$ & $x$ & $x$ & \\
\hline $\begin{array}{l}\text { Orthosia (Microrthosia) cruda } \\
\text { ([Denis \& Schiffermüller], 1775) }\end{array}$ & 4 & $x$ & $x$ & $x$ & \\
\hline $\begin{array}{l}\text { Orthosia (Cororthosia) gracilis } \\
\text { ([Denis \& Schiffermüller], 1775) }\end{array}$ & 3 & $x$ & $x$ & & \\
\hline $\begin{array}{l}\text { Orthosia (Semiophora) gothica } \\
\text { (Linnaeus, 1758) }\end{array}$ & 164 & $x$ & $x$ & $x$ & \\
\hline $\begin{array}{l}\text { Egira conspicillaris } \\
\text { (Linnaeus, 1758) }\end{array}$ & 27 & $x$ & $x$ & & \\
\hline $\begin{array}{l}\text { Tholera cespitis } \\
\text { ([Denis \& Schiffermüller], 1775) }\end{array}$ & 62 & $x$ & & & \\
\hline $\begin{array}{l}\text { Tholera decimalis } \\
\text { (Poda, 1761) }\end{array}$ & 15 & & & & \\
\hline
\end{tabular}




\begin{tabular}{|c|c|c|c|c|c|}
\hline Taxonok & $\begin{array}{c}\text { Kanizsaberek } \\
\text { fénycsapda és } \\
\text { nappali mintavételek }\end{array}$ & $\begin{array}{l}\text { 1. mintavételi } \\
\text { hely }\end{array}$ & $\begin{array}{l}\text { 2. mintavételi } \\
\text { hely }\end{array}$ & $\begin{array}{l}\text { 3. mintavételi } \\
\text { hely }\end{array}$ & $\begin{array}{c}\text { Irodalmi adatok (Kovács } \\
\text { 1953, Ábrahám 1989, } \\
\text { Uherkovich 1997) }\end{array}$ \\
\hline $\begin{array}{l}\text { Euxoa obelisca } \\
\text { ([Denis \& Schiffermüller], 1775) }\end{array}$ & 3 & & $\mathrm{x}$ & & \\
\hline $\begin{array}{l}\text { Euxoa segnilis } \\
\text { (Duponchel, 1837) }\end{array}$ & 2 & $\mathrm{x}$ & & & \\
\hline $\begin{array}{l}\text { Agrotis bigramma } \\
\text { (Esper, 1790) }\end{array}$ & 3 & & $\mathrm{x}$ & & \\
\hline $\begin{array}{l}\text { Agrotis exclamationis } \\
\text { (Linnaeus, 1758) }\end{array}$ & 43 & $x$ & $\mathrm{x}$ & $x$ & \\
\hline $\begin{array}{l}\text { Agrotis segetum } \\
\text { ([Denis \& Schiffermüller], 1775) }\end{array}$ & 28 & $\mathrm{x}$ & $x$ & $\mathrm{x}$ & \\
\hline $\begin{array}{l}\text { Agrotis ipsilon } \\
\text { (Hufnagel, 1766) }\end{array}$ & 2 & & $\mathrm{x}$ & & \\
\hline $\begin{array}{l}\text { Agrotis vestigialis } \\
\text { (Hufnagel, 1766) }\end{array}$ & 4 & & $\mathrm{x}$ & & \\
\hline $\begin{array}{l}\text { Axylia putris } \\
\text { (Linnaeus, 1761) }\end{array}$ & 226 & $\mathrm{x}$ & $\mathrm{x}$ & $\mathrm{x}$ & \\
\hline $\begin{array}{l}\text { Ochropleura plecta } \\
\text { (Linnaeus, 1761) }\end{array}$ & 104 & $x$ & $\mathrm{x}$ & $x$ & \\
\hline $\begin{array}{l}\text { Diarsia rubi } \\
\text { (Vieweg, 1790) }\end{array}$ & 29 & $\mathrm{x}$ & $\mathrm{x}$ & $\mathrm{x}$ & \\
\hline $\begin{array}{l}\text { Cerastis rubricosa } \\
\text { ([Denis \& Schiffermüller], 1775) }\end{array}$ & 1 & & $x$ & & $\mathrm{x}$ \\
\hline $\begin{array}{l}\text { Cerastis leucographa } \\
\text { ([Denis \& Schiffermüller], 1775) }\end{array}$ & 1 & & $\mathrm{x}$ & & $\mathrm{x}$ \\
\hline $\begin{array}{l}\text { Noctua pronuba } \\
\text { (Linnaeus, 1758) }\end{array}$ & 20 & $\mathrm{x}$ & $\mathrm{x}$ & & \\
\hline $\begin{array}{l}\text { Noctua fimbriata } \\
\text { (Schreber, 1759) }\end{array}$ & 3 & & & $\mathrm{x}$ & \\
\hline Noctua comes Hübner, 1813 & 1 & & & & $x$ \\
\hline $\begin{array}{l}\text { Noctua janthina } \\
\text { ([Denis \& Schiffermüller], 1775) }\end{array}$ & & & & $\mathrm{x}$ & \\
\hline $\begin{array}{l}\text { Xestia (Xestia) baja } \\
\text { ([Denis \& Schiffermüller], 1775) }\end{array}$ & 3 & & $\mathrm{x}$ & & $\mathrm{x}$ \\
\hline $\begin{array}{l}\text { Xestia (Xestia) xanthographa } \\
\text { ([Denis \& Schiffermüller], 1775) }\end{array}$ & 50 & $\mathrm{x}$ & $\mathrm{x}$ & & \\
\hline $\begin{array}{l}\text { Xestia (Megasema) c-nigrum } \\
\text { (Linnaeus, 1758) }\end{array}$ & 61 & $\mathrm{x}$ & $\mathrm{x}$ & & \\
\hline $\begin{array}{l}\text { Xestia (Megasema) triangulum } \\
\text { (Hufnagel, 1766) }\end{array}$ & 19 & $\mathrm{x}$ & & & $\mathrm{x}$ \\
\hline \multicolumn{6}{|l|}{ Hesperiidae Latreille, 1809} \\
\hline $\begin{array}{l}\text { Erynnis tages } \\
\text { (Linnaeus, 1758) }\end{array}$ & $x$ & & & & \\
\hline $\begin{array}{l}\text { Pyrgus malvae } \\
\text { (Linnaeus, 1758) }\end{array}$ & $x$ & & & & \\
\hline $\begin{array}{l}\text { Pyrgus serratulae } \\
\text { (Rambur, 1839) }\end{array}$ & $\mathrm{x}$ & & & & $\mathrm{x}$ \\
\hline $\begin{array}{l}\text { Pyrgus carthami } \\
\text { (Hübner, [1813]) }\end{array}$ & & & & & $\mathrm{x}$ \\
\hline $\begin{array}{l}\text { Carterocephalus palaemon } \\
\text { (Pallas, 1771) }\end{array}$ & & & & & $\mathrm{x}$ \\
\hline $\begin{array}{l}\text { Heteropterus morpheus } \\
\text { (Pallas, 1771) }\end{array}$ & $\mathrm{x}$ & & & & \\
\hline $\begin{array}{l}\text { Ochlodes sylvanus } \\
\text { (Esper, 1779) }\end{array}$ & $\mathrm{x}$ & & & & \\
\hline $\begin{array}{l}\text { Thymelicus lineola } \\
\text { (Ochsenheimer, 1808) }\end{array}$ & $\mathrm{x}$ & & & & $\mathrm{x}$ \\
\hline $\begin{array}{l}\text { Thymelicus sylvestris } \\
\text { (Poda, 1761) }\end{array}$ & $\mathrm{x}$ & & & & $\mathrm{x}$ \\
\hline \multicolumn{6}{|l|}{ Papilionidae Latreille, [1802] } \\
\hline $\begin{array}{l}\text { Iphiclides podalirius } \\
\text { (Linnaeus, 1758) }\end{array}$ & $\mathrm{x}$ & & & & \\
\hline Papilio machaon Linnaeus, 1758 & $x$ & & & & $\mathrm{x}$ \\
\hline
\end{tabular}




\begin{tabular}{|c|c|c|c|c|c|}
\hline Taxonok & $\begin{array}{c}\text { Kanizsaberek } \\
\text { fénycsapda és } \\
\text { nappali mintavételek }\end{array}$ & $\begin{array}{l}\text { 1. mintavételi } \\
\text { hely }\end{array}$ & $\begin{array}{l}\text { 2. mintavételi } \\
\text { hely }\end{array}$ & $\begin{array}{l}\text { 3. mintavételi } \\
\text { hely }\end{array}$ & $\begin{array}{c}\text { Irodalmi adatok (Kovács } \\
\text { 1953, Ábrahám 1989, } \\
\text { Uherkovich 1997) }\end{array}$ \\
\hline \multicolumn{6}{|l|}{ Pieridae Duponchel [1835] } \\
\hline $\begin{array}{l}\text { Colias hyale } \\
\text { (Linnaeus, 1758) }\end{array}$ & $x$ & & & & $x$ \\
\hline Colias alfacariensis Ribbe, 1905 & $\mathrm{x}$ & & & & \\
\hline $\begin{array}{l}\text { Colias croceus } \\
\text { (Geoffroy in Fourcroy, 1785) }\end{array}$ & $x$ & & & & \\
\hline $\begin{array}{l}\text { Gonepteryx rhamni } \\
\text { (Linnaeus, 1758) }\end{array}$ & $x$ & & & & \\
\hline $\begin{array}{l}\text { Leptidea sinapis } \\
\text { (Linnaeus, 1758) }\end{array}$ & $\mathrm{x}$ & & & & $x$ \\
\hline $\begin{array}{l}\text { Pieris (Pieris) brassicae } \\
\text { (Linnaeus, 1758) }\end{array}$ & $\mathrm{x}$ & & & & \\
\hline $\begin{array}{l}\text { Pieris (Artogeia) rapae } \\
\text { (Linnaeus, 1758) }\end{array}$ & $x$ & & & & $\mathrm{x}$ \\
\hline $\begin{array}{l}\text { Pieris (Artogeia) napi } \\
\text { (Linnaeus, 1758) }\end{array}$ & $x$ & & & & \\
\hline $\begin{array}{l}\text { Pontia daplidice edusa } \\
\text { (Fabricius, 1777) }\end{array}$ & $x$ & & & & \\
\hline $\begin{array}{l}\text { Anthocharis cardamines } \\
\text { (Linnaeus, 1758) }\end{array}$ & $x$ & & & & \\
\hline \multicolumn{6}{|l|}{ Riodinidae Grote, 1895} \\
\hline $\begin{array}{l}\text { Hamearis lucina } \\
\text { (Linnaeus, } 1758\end{array}$ & $x$ & & & & \\
\hline \multicolumn{6}{|l|}{ Lycaenidae [Leach], [1815] } \\
\hline $\begin{array}{l}\text { Lycaena dispar rutilus } \\
\text { (Werneburg, 1864) }\end{array}$ & $x$ & & & & \\
\hline $\begin{array}{l}\text { Lycaena phlaeas } \\
\text { (Linnaeus, 1761) }\end{array}$ & $x$ & & & & \\
\hline $\begin{array}{l}\text { Lycaena hippothoe } \\
\text { (Linnaeus, 1761) }\end{array}$ & $x$ & & & & \\
\hline $\begin{array}{l}\text { Lycaena alciphron } \\
\text { (Rottemburg, 1775) }\end{array}$ & & & & & $\mathrm{x}$ \\
\hline $\begin{array}{l}\text { Lycaena tityrus } \\
\text { (Poda, 1761) }\end{array}$ & $x$ & & & & $x$ \\
\hline $\begin{array}{l}\text { Callophrys rubi } \\
\text { (Linnaeus, 1758) }\end{array}$ & $x$ & & & & \\
\hline $\begin{array}{l}\text { Satyrium pruni } \\
\text { (Linnaeus, 1758) }\end{array}$ & $x$ & & & & \\
\hline $\begin{array}{l}\text { Celastrina argiolus } \\
\text { (Linnaeus, 1758) }\end{array}$ & $x$ & & & & \\
\hline $\begin{array}{l}\text { Cupido (Everes) argiades } \\
\text { (Pallas, 1771) }\end{array}$ & $x$ & & & & $x$ \\
\hline $\begin{array}{l}\text { Cupido (Everes) alcetas } \\
\text { (Hoffmannsegg, 1804) }\end{array}$ & $x$ & & & & $x$ \\
\hline $\begin{array}{l}\text { Scolitantides orion } \\
\text { (Pallas, 1771) }\end{array}$ & & & & & $x$ \\
\hline $\begin{array}{l}\text { Glaucopsyche alexis } \\
\text { (Poda, 1761) }\end{array}$ & $x$ & & & & \\
\hline $\begin{array}{l}\text { Maculinea nausithous } \\
\text { (Bergstrasser, 1779) }\end{array}$ & $x$ & & & & \\
\hline $\begin{array}{l}\text { Maculinea teleius } \\
\text { (Bergstrasser, 1779) }\end{array}$ & $x$ & & & & $x$ \\
\hline $\begin{array}{l}\text { Plebejus (Plebejus) argus } \\
\text { (Linnaeus, 1758) }\end{array}$ & $x$ & & & & \\
\hline $\begin{array}{l}\text { Plebejus (Plebejus) } \\
\text { argyrognomon } \\
\text { (Bergstrasser, 1779) }\end{array}$ & $x$ & & & & $x$ \\
\hline $\begin{array}{l}\text { Aricia agestis } \\
\text { ([Denis \& Schiffermüller], 1775) }\end{array}$ & $x$ & & & & $x$ \\
\hline $\begin{array}{l}\text { Cyaniris semiargus } \\
\text { (Rottemburg, 1775) }\end{array}$ & $x$ & & & & $x$ \\
\hline $\begin{array}{l}\text { Polyommatus } \\
\text { (Polyommatus) icarus } \\
\text { (Rottemburg, 1775) }\end{array}$ & $x$ & & & & $x$ \\
\hline
\end{tabular}




\begin{tabular}{|c|c|c|c|c|c|}
\hline Taxonok & $\begin{array}{c}\text { Kanizsaberek } \\
\text { fénycsapda és } \\
\text { nappali mintavételek }\end{array}$ & $\begin{array}{l}\text { 1. mintavételi } \\
\text { hely }\end{array}$ & $\begin{array}{l}\text { 2. mintavételi } \\
\text { hely }\end{array}$ & $\begin{array}{l}\text { 3. mintavételi } \\
\text { hely }\end{array}$ & $\begin{array}{c}\text { Irodalmi adatok (Kovács } \\
\text { 1953, Ábrahám 1989, } \\
\text { Uherkovich 1997) }\end{array}$ \\
\hline Nymphalidae Swainson, 1827 & & & & & $\mathrm{x}$ \\
\hline $\begin{array}{l}\text { Neptis sappho } \\
\text { (Pallas, 1771) }\end{array}$ & $\mathrm{x}$ & & & & $x$ \\
\hline $\begin{array}{l}\text { Argynnis paphia } \\
\text { (Linnaeus, 1758) }\end{array}$ & $\mathrm{x}$ & & & & \\
\hline $\begin{array}{l}\text { Argynnis pandora } \\
\text { ([Denis \& Schiffermüller], 1775) }\end{array}$ & & & & & $\mathrm{x}$ \\
\hline $\begin{array}{l}\text { Argynnis adippe } \\
\text { (Linnaeus, 1758) }\end{array}$ & $\mathrm{x}$ & & & & $x$ \\
\hline $\begin{array}{l}\text { Issoria lathonia } \\
\text { (Linnaeus, 1758) }\end{array}$ & $\mathrm{x}$ & & & & \\
\hline $\begin{array}{l}\text { Brenthis daphne } \\
\text { ([Denis \& Schiffermüller], 1775) }\end{array}$ & $x$ & & & & \\
\hline $\begin{array}{l}\text { Boloria (Clossiana) dia } \\
\text { (Linnaeus, 1767) }\end{array}$ & $x$ & & & & $\mathrm{x}$ \\
\hline $\begin{array}{l}\text { Boloria (Clossiaua) euphrosyne } \\
\text { (Linnaeus, 1758) }\end{array}$ & $\mathrm{x}$ & & & & \\
\hline $\begin{array}{l}\text { Boloria (Clossiana) selene } \\
\text { ([Denis \& Schiffermüller], 1775) }\end{array}$ & $\mathrm{x}$ & & & & \\
\hline $\begin{array}{l}\text { Apatura ilia } \\
\text { ([Denis \& Schiffermüller], 1775) }\end{array}$ & $\mathrm{x}$ & & & & \\
\hline $\begin{array}{l}\text { Melitaea (Melitaea) cinxia } \\
\text { (Linnaeus, 1758) }\end{array}$ & $\mathrm{x}$ & & & & \\
\hline $\begin{array}{l}\text { Melitaea (Melitaea) didyma } \\
\text { (Esper, 1779) }\end{array}$ & $\mathrm{x}$ & & & & $x$ \\
\hline $\begin{array}{l}\text { Melitaea (Melitaea) phoebe } \\
\text { ([Denis \& Schiffermüller], 1775) }\end{array}$ & $\mathrm{x}$ & & & & \\
\hline $\begin{array}{l}\text { Melitaea (Melitaea) trivia } \\
\text { ([Denis \& Schiffermüller], 1775) }\end{array}$ & $\mathrm{x}$ & & & & \\
\hline $\begin{array}{l}\text { Melitaea (Mellicta) athalia } \\
\text { (Rottemburg, 1775) }\end{array}$ & $\mathrm{x}$ & & & & \\
\hline $\begin{array}{l}\text { Melitaea (Mellicta) aurelia Nickerl, } \\
1850\end{array}$ & $x$ & & & & $x$ \\
\hline $\begin{array}{l}\text { Araschnia levana } \\
\text { (Linnaeus, 1758) }\end{array}$ & $x$ & & & & \\
\hline $\begin{array}{l}\text { Nymphalis (Inachis) io } \\
\text { (Linnaeus, 1758) }\end{array}$ & $x$ & & & & $\mathrm{x}$ \\
\hline $\begin{array}{l}\text { Nymphalis (Aglais) urticae } \\
\text { (Linnaeus, 1758) }\end{array}$ & $\mathrm{x}$ & & & & \\
\hline $\begin{array}{l}\text { Nymphalis (Polygonia) c-album } \\
\text { (Linnaeus, } 1758\end{array}$ & $\mathrm{x}$ & & & & \\
\hline $\begin{array}{l}\text { Vanessa atalanta } \\
\text { (Linnaeus, 1758) }\end{array}$ & $\mathrm{x}$ & & & & \\
\hline $\begin{array}{l}\text { Vanessa cardui } \\
\text { (Linnaeus, 1758) }\end{array}$ & $x$ & & & & \\
\hline $\begin{array}{l}\text { Pararge aegeria tircis } \\
\text { (Godart, 1821) }\end{array}$ & $\mathrm{x}$ & & & & \\
\hline $\begin{array}{l}\text { Lasiommata megera } \\
\text { (Linnaeus, 1767) }\end{array}$ & $x$ & & & & \\
\hline $\begin{array}{l}\text { Coenonympha arcania } \\
\text { (Linnaeus, 1761) }\end{array}$ & $\mathrm{x}$ & & & & \\
\hline $\begin{array}{l}\text { Coenonympha glycerion } \\
\text { (Borkhausen, 1788) }\end{array}$ & $\mathrm{x}$ & & & & \\
\hline $\begin{array}{l}\text { Coenonympha pamphilus } \\
\text { (Linnaeus, 1758) }\end{array}$ & $x$ & & & & \\
\hline $\begin{array}{l}\text { Aphantopus hyperanthus } \\
\text { (Linnaeus, } 1758\end{array}$ & $\mathrm{x}$ & & & & $\mathrm{x}$ \\
\hline $\begin{array}{l}\text { Maniola jurtina } \\
\text { (Linnaeus, 1758) }\end{array}$ & $\mathrm{x}$ & & & & $\mathrm{x}$ \\
\hline $\begin{array}{l}\text { Melanargia galathea } \\
\text { (Linnaeus, 1758) }\end{array}$ & $\mathrm{x}$ & & & & \\
\hline $\begin{array}{l}\text { Minois dryas } \\
\text { (Scopoli, 1763) }\end{array}$ & $\mathrm{x}$ & & & & \\
\hline $\begin{array}{l}\text { Brintesia circe } \\
\text { (Linnaeus, 1758) }\end{array}$ & $x$ & & & & \\
\hline
\end{tabular}




\section{Irodalom}

ÁBRAHÁM L. 1989: Nattán Miklós nagylepke gyűjteménye (Lepidoptera) a pécsi Janus Pannonius Múzeumban. - A Janus Pannonius Múzeum Évkönyve 34: 63-71.

ÁBRAHÁM L. 1995: Rovarfaunisztikai kutatási eredmények (Baláta-tó TT, Szársomlyó TT). - DDNP, kutatási jelentés.

ÁBRAHÁM L. \& PAPP Z. 1991: Myrmeleon bore (Tjeder, 1941) in Hungary (Planipennia, Myrmeleontidae) - Neuroptera International 6(3): 137-139.

ÁBRAHÁM L. 1992: Boronka-melléki Tájvédelmi Körzet nagylepkefaunájának természetvédelmi feltárása I. (Lepidoptera). Dunántúli Dolgozatok Természettudományi Sorozat 7: 241-271.

ÁBRAHÁM L. és UHERKOVICH Á. 1998: A Dráva mente nagylepke faunája és jellegzetes élöhelyei (Lepidoptera). - Dunántúli Dolgozatok Természettudományi Sorozat 9: 359-385.

ÁBRAHÁm L. és UHERKovich Á. 2001: Somogy nagylepke faunájának katalógusa (Lepidoptera: Macrolepidoptera). - Natura Somogyiensis 1: 329-374.

BORHIDI A. \& JÁRAI-KOMLÓDI M. 1959: Die Vegetation des Naturschutzgebietes des Baláta-sees. Acta Botanica Hungarica 5.: 259-320.

BorhidI A., KeVey B., MAJer J. és Oroszné Kovács Zs. 1990: A környezetváltozás tendenciáinak felmérése és monitoringja déldunántúli lápterületeken. - Kézirat, Pécs

BÉRCES S. 2002: Adatok a Baláta-tói Természetvédelmi terület futóbogárfaunájához (Coleoptera: Carabidae). - Somogyi Múzeumok Közleményei 15: 123-128.

JózAN Zs. 1996: A Baláta környék fullánkos hártyásszárnyú faunájának (Hym., Aculeata) alapvetése. - Somogyi Múzeumok Közleményei 12: 271-296.

HARIS, A. 2012: Sawflies of Belső-Somogy (Hymenoptera: Symphyta). - Natura Somogyiensis 22: 141-162.

KovÁcs L., 1953. A magyarországi nagylepkék és elterjedésük. - Folia entomologica hungarica 6(1): 77-184.

KovÁcs L., 1956. A magyarországi nagylepkék és elterjedésük II. Folia entomologica hungarica 9(1): 89-140.

MAJER J. 1992: A Baláta-tó zoológiai felmérése (különös tekintettel a madárfaunára) (1989-1990). - Somogyi Múzeumok Közleményei 9: 321-327.
MAJER J., M. BordÁcs M. és BorHIDI A. 2002: A Baláta-tó vízminőségének alapállapot felvételezése. - Somogyi Múzeumok Közleményei 15: 97-106.

MARIÁN M. 1956: Adatok a keresztes vipera (Vipera b. berus L.) somogyi elterjedési viszonyaihoz - Annales Muzei Nationalis Hungarici, 7: 453-468.

MARIÁN M. 1957: A Baláta gerinces állatvilága - Somogyi Almanach 1: 1-59.

MARIÁN M. 1958:ABaláta gerinces állatvilágáról.-Természettudományi Közlöny 89(3):119-123.

SümegI P., NÁfrÁdI K., JAKAB G., Persaits G. és TÖRŐcsıK T. 2014: A Baláta-tó környezettörténete. - A Kaposvári Rippl-Rónai Múzeum Közleményei 3: 5-28.

SzUNYOGHY J. 1972: Rovarok - Insectivora - Magyarország állatvilága XXII. 1. Akadémiai Kiadó, Budapest

UHERKOVICH Á. 1978: A Barcsi Ősborókás nagylepkefaunája I. (Lepidoptera). - Dunántúli Dolgozatok Természettudományi Sorozat 1: $93-125$.

UHERKOVICH Á 1981: A Barcsi Borókás nagylepkefaunája II. (Lepidoptera). - Dunántúli Dolgozatok Természettudományi Sorozat 2: 89-125.

UHERKovich Á. 1983: A Barcsi Borókás nagylepkefaunája III. (Lepidoptera). - Dunántúli Dolgozatok Természettudományi Sorozat 3: 55-72.

UHERKoVICH Á. (szerk.) 1997: A Baláta-tó és környéke zoológiai kutatásának néhány eddigi eredménye. - Janus Pannonius Múzeum, Pécs TvH, kutatási jelentés.

UHERKOVICH Á. és ÁBRAHÁm L. 1995: A nagylepke (Lepidoptera: Macrolepidoptera) kutatások faunisztikai eredményei a Dráva mentén. - Dunántúli Dolgozatok Természettudományi Sorozat 8: 139-159.

Tо́тн S. 2010: A Dunántúli-dombság és környéke szitakötő faunája. Natura Somogyiensis 16: 1-198.

VARGA Z. (szerk.) 2012: Magyarország nagylepkéi. - Második javított kiadás, Heterocera Press, Budapest pp. 1-256. 